\title{
Potential of Pervaporation and Vapor Separation with Water Selective Membranes for an Optimized Production of Biofuels-A Review
}

\author{
Catia Cannilla *, Giuseppe Bonura and Francesco Frusteri \\ National Council of Research, Institute for Advanced Energy Technologies "Nicola Giordano", CNR-ITAE, \\ via S. Lucia sopra Contesse 5, 98126 Messina, Italy; giuseppe.bonura@itae.cnr.it (G.B.); \\ francesco.frusteri@itae.cnr.it (F.F.) \\ * Correspondence: catia.cannilla@itae.cnr.it; Tel.: +39-090-624-238 \\ Academic Editor: Martin van Sint Annaland \\ Received: 28 April 2017; Accepted: 4 June 2017; Published: 9 June 2017
}

\begin{abstract}
The development of processes based on the integration of new technologies is of growing interest to industrial catalysis. Recently, significant efforts have been focused on the design of catalytic membrane reactors to improve process performance. In particular, the use of membranes, that allow a selective permeation of water from the reaction mixture, positively affects the reaction evolution by improving conversion for all reactions thermodynamically or kinetically limited by the presence of water. In this paper, how pervaporation (PV) and vapor permeation (VP) technologies can improve the catalytic performance of reactions of industrial interest is considered. Specifically, technological approaches proposed in the literature are discussed with the aim of highlighting advantages and problems encountered in order to address research towards the optimization of membrane reactor configurations for liquid biofuel production in large scale.
\end{abstract}

Keywords: pervaporation; vapor permeation; biofuels production; membranes

\section{Introduction}

In chemical reactions which are equilibrium limited, such as etherification, acetalization, transesterification, esterification, hydrolysis or alkylation, to improve the productivity, it is possible to shift the position of equilibrium towards the products by using an excess of reactants or by removing products. Using an excess of reactant would result in increased cost of the subsequent separation as the product stream is in diluted form. On the other hand, the removal of the product via processes such as reactive distillation requires a sufficiently large difference in the volatility of product and reactants. Moreover, the mismatching of the reaction and distillation temperature is a complication and in many cases the process performance and energy consumption (large reflux ratios) in reactive distillation are the major cost factors [1]. Then, if the solution forms an azeotrope, the reactive distillation process could be unsuited [2].

On this account, in recent decades, the need of cheaper and more competitive technologies has led to the "process intensification" idea, with the design of compact catalytic reactors, by developing new process designs or reorganizing current process designs. One of the objectives could be, for example, the development of reactive separations, or rather integrated operations combining reaction and separation functions for the simultaneous production and removal of products or byproducts. This configuration could increase productivity and selectivity, decrease the energy consumption, eliminate the need for solvents, and lead to high-efficiency systems with green engineering features. Generally, some of these benefits are achieved by exploiting either the reactions to enhance separation or the separation process to improve reactions (e.g., overcoming equilibrium constraints, enhancing 
the reaction rates, increasing selectivity), since the optimal configuration could be realized if both processes are improved [3,4].

In several industrial chemical reactions, for example, water is a by-product which has a severe inhibitor effect on catalytic activity causing low conversion and productivity. On this account, by promoting the in situ water removal, it should be possible to achieve several important goals: (i) to overcome the reaction thermodynamic constraints and (ii) to avoid the catalyst deactivation due to poisoning. Up to today, most industrial scale separation processes to remove the water from a reaction mixture have been based on energy intensive methods such as heteroazeotropic distillation [5], sparging of dry inert gas through the reaction medium [6], use of salt hydrates [7,8], evaporation and freeze crystallization [9], and sorption [4,10]. So, new technologies, such as membrane reactors (MR) [4], based on the integration of membrane separation and chemical reaction [3,11-20], have been suggested in the attempt to improve the performance of a catalytic system by less energy-intensive processes. The science and technology of membranes, in fact, offer innovative solutions for design, rationalization, and optimization of production cycles, showing superior efficiency than conventional separation and reaction operations. Various membrane technologies are already available for different industrial applications (i.e., agro-food product formulation or chemical production, water desalination or wastewater treatments), like reverse osmosis, gas separation, ultrafiltration, nanofiltration, microfiltration, pervaporation or vapor permeation, and dialysis [21].

A membrane represents a semi-permeable active or passive barrier which selectively allows the separation of one or more species (liquids, gases or vapors) of a mixture by their passage from one side to the other, at different mass transfer rates, due to a different permeability, governed by the physical and/or chemical interaction between the membrane and the permeating species. The driving force required for the permeation of a component could be the concentration or pressure difference through the membrane [22]. Till now, the membrane separation has been applied mainly in gas phase reactions, like synthesis gas production and dehydrogenations, whereas only a few papers regard the use of water-permeable membranes for liquid-phase processes, even if many equilibrium-limited liquid phase mixtures could be treated with the same technology [23-28]. Specifically, in this paper, attention will be focused on some liquid reactions employed for biofuels and additives production, by reviewing some model reactions and some new applications in which pervaporation (PV) and vapor permeation (VP) are exploited for in situ water removal. The alternative fuels here discussed, like biodiesel from esterification of fatty acids and gasoline additives (i.e., ethers and acetals), in fact, are produced by catalyzed reactions where the water represents the undesired product.

Specifically, in their simplest form, PV and VP could be considered as clean technologies, which, because of low temperatures and pressures involved, could efficiently replace conventional energy-intensive separation processes. The ability of PV and VP to handle azeotropic mixtures, avoiding the constraints imposed by liquid-vapor equilibrium, in fact, makes these processes extremely attractive and competitive especially if integrated with other separation methods. It has been reported that membranes could save up to $85 \%$ of the energy demands required by distillation technology, with a positive decrease in the energy cost of 30-50\% [29]. Separation by PV and VP does not depend on the relative volatilities rather on the relative permeation rates through a membrane, being based on the affinity with membrane materials so that the component having the higher affinity is adsorbed and diffuses through the membrane, while the barrier retains molecules having low affinity [1]. Nowadays, dehydration of organic solvents represents the largest PV industrial application, in which the high water diffusivity through the membrane contributes positively to the selectivity of these processes [30]. As a general example, a comparison of different techniques used for ethanol dehydration shows that operating costs of PV and VP technologies are smaller than other approaches [31-33]. 


\section{Pervaporation and Vapor Permeation Principles}

Separation via pervaporation (PV) or vapor permeation (VP) is based on a solution-diffusion mechanism across the membrane. The main advantages of such processes and a comparison between PV and VP are summarized in Tables 1 and 2 [34].

Table 1. Main advantages of the use of PV and VP technologies [34].

\begin{tabular}{l}
\hline Highlights of PV and VP Processes \\
\hline Mixtures that at normal distillation form azeotropes and/or require a large number of theoretical stages can \\
easily and economically be separated even without the use of entrained agents (chemicals). \\
\hline High product purity is obtained and no environmental pollution occurs. \\
\hline Multicomponent mixtures with small difference in boiling points can be dehydrated effectively \\
and economically. \\
\hline The feed mixtures could be in either liquid or vapor form. \\
Low energy consumption is required. \\
Small units can operate economically exploiting the modular design of the membrane system. \\
High degrees of feed mixture flexibility. \\
High final product qualities are obtained \\
\hline $\begin{array}{l}\text { Modularly, compact design and factory-preassembled systems are simple to operate and can be started up and } \\
\text { shut down rapidly. }\end{array}$ \\
\hline
\end{tabular}

Table 2. Comparison between PV and VP technologies.

\begin{tabular}{|c|c|}
\hline Pervaporation & Vapor Permeation \\
\hline - $\quad$ The feed is a liquid. & $\begin{array}{l}\text { - The feed is a mixture of vapor or vapor } \\
\text { and gases. }\end{array}$ \\
\hline $\begin{array}{l}\text { - Liquid-vapor phase change is required, } \\
\text { involving the enthalpy of vaporization. } \\
\text { - Heat exchangers could be required. }\end{array}$ & $\begin{array}{l}\text { - No change of phase and no significant } \\
\text { temperature difference across the membrane } \\
\text { are required. } \\
\text { - Heat exchangers can be dispensed with. }\end{array}$ \\
\hline $\begin{array}{l}\text { The driving force for PV process is the } \\
\text { difference in chemical potential, concentration } \\
\text { gradient between phases on the opposite sides } \\
\text { of the interfacial barrier. }\end{array}$ & $\begin{array}{l}\text { - The driving force is the partial pressures of the } \\
\text { components in the feed. }\end{array}$ \\
\hline $\begin{array}{l}\text { - There is no possibility of increasing the driving } \\
\text { force by pressure in the feed compartment. }\end{array}$ & $\begin{array}{l}\text { - It is possible to increase the driving force by } \\
\text { pressure augment. }\end{array}$ \\
\hline $\begin{array}{l}\text { - Permeate must be volatile at } \\
\text { operating conditions. }\end{array}$ & $\begin{array}{l}\text { - Larger modules could be used and the scale-up } \\
\text { of the MR makes it easier. }\end{array}$ \\
\hline $\begin{array}{l}\text { - The membrane is in contact with the liquid feed, } \\
\text { so it could be poisoned during the reaction. }\end{array}$ & $\begin{array}{l}\text { - Long membrane lifetime since the membrane is } \\
\text { not in direct contact with the } \\
\text { reaction environment. }\end{array}$ \\
\hline $\begin{array}{l}\text { - Highly swollen membranes could favor } \\
\text { greater fluxes. }\end{array}$ & $\begin{array}{l}\text { Water permselectivity is increased, fluxes of } \\
\text { water in certain systems are higher and lower } \\
\text { membrane area is required. }\end{array}$ \\
\hline
\end{tabular}

\subsection{Pervaporation (PV)}

The word "pervaporation" derives from the two basic steps of the process: permeation and evaporation. Many models could be employed to describe it, however the main principle is the separation of liquid mixtures by partial vaporization through a dense membrane, thus a liquid-vapor phase change is required. Specifically, the passage of a species across the membrane could be explained by the solution-desorption model which results from the following steps: (i) diffusion of the component through the liquid boundary layer to the membrane surface; (ii) sorption/transport of adsorbed 
species through the membrane according to Fick's law; (iii) desorption at the permeate side into vapor phase [34]. Commonly, the partial vapor pressure difference between the feed solution and the permeate is achieved by employing a sweep gas or vacuum at the permeate side (see Figure 1). In industrial PV, vacuum is generally used to avoid the need of a secondary separation step from the sweep gas and then vapors are liquefied in a pre-condenser and a liquid-ring pump [1]. In modeling the transport process, the resistance at the boundary layer of the vapor phase is assumed negligible and the concentration of the solute is considered zero at the permeate side, where a low vacuum level is maintained. When permeant pressure increases, the resistance to transport on the vapor side will increase too, becoming significant [1].
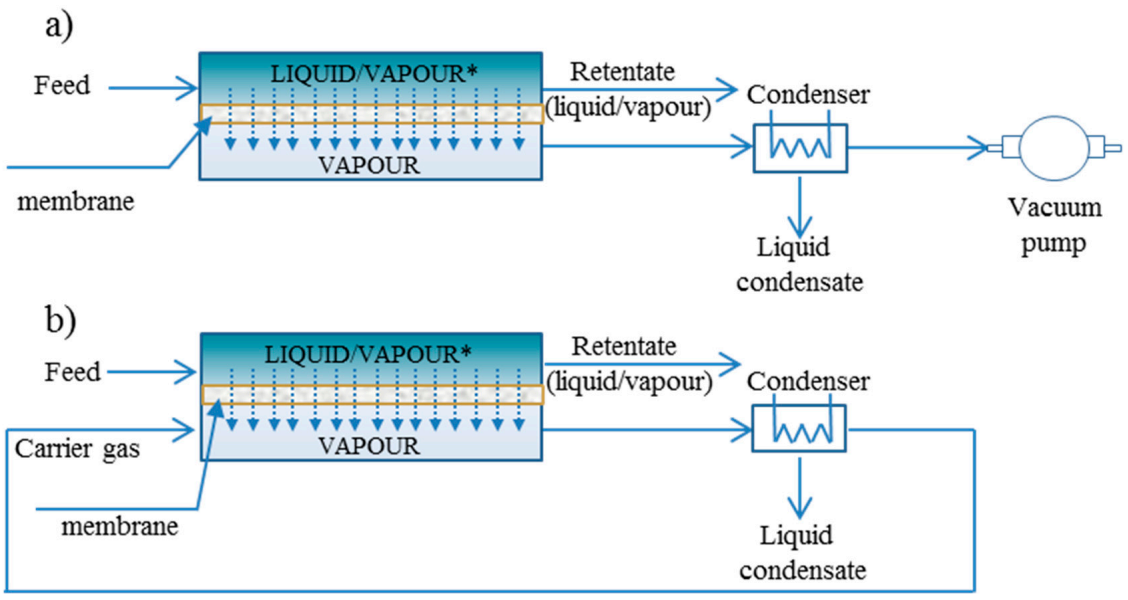

Figure 1. Schematic PV or VP process: (a) by vacuum; (b) by carrier gas. ${ }^{*}$ For PV, the feed is liquid; for $\mathrm{VP}$, the feed is vapor.

PV involves not only mass transport through the membrane but also heat transfer, considering that the change of the physical state from a liquid solution to a vapor solution requires the enthalpy of vaporization which is ensured by the liquid feed stream. Consequently, a reduction of the feed temperature takes place [30]. The liquid mixture is pre-heated to the reaction temperature and sent to the separation unit. The permeate is vaporized on the permeate side of the membrane and the heat is dissipated from the feed. When, due to decreasing temperature, the partial pressure of the transported species and the driving force for mass transportation decrease too, the feed solution is re-heated. The re-heating could take place outside the modules by employing additional heat exchangers. Consequently, at an industrial scale, many small membrane modules with upstream heat exchangers should be furnished.

It is extremely important to ensure the best conditions for mass transfer of target compounds through the boundary layer at the liquid/membrane interface. Only when an adequate membrane is selected, will target solutes have the proper affinity with the membrane ensuring their high partitioning and consequently high driving force for diffusion across the membrane. The adsorption process derives from fugacity of involved feed species, depending in turn on molar concentration values. Since liquids are nearly incompressible, there is no possibility of increasing the driving force by increasing pressure on the feed side [35]. On account of this, if compared with VP, PV is limited by the relatively low concentration of compounds in the feed phase aimed to be transported across the membrane, limiting the driving force and ultimately the flux.

On lab-scale, the flux values of PV are generally evaluated by weighing the permeate amount collected in a liquid nitrogen trap over a given time period. Such values are usually indicated by $\mathrm{kg} / \mathrm{m}^{2}$ units, which are also used in industrial separations.

On the whole, PV processes are characterized by low energy consumption, only heat being necessary for the permeating water evaporation, thus being a very attractive solution. Additionally, 
the reaction can be performed at a temperature independent of the reflux one, and the efficiency of separation in PV is not solely fixed by the relative volatility as in reactive distillation [36].

\subsection{Vapor Permeation (VP)}

In vapor permeation, the feed is a mixture of vapors or vapors and gases and not a liquid. Contrary to $\mathrm{PV}$, considering that no change of phase is involved, the addition of heat, equivalent to the enthalpy of vaporization, is not required and there is no important temperature difference across the membrane. As for PV, the determining factor is represented by the molecular interaction between each component and the membrane. The membrane, in fact, is exploited as a semi-permeable barrier between the feed side under high pressure and the permeate side under low pressure [37], thus the driving force can be approximated to the chemical potential gradient established by applying a difference in the partial pressures of permeate across the membrane, the separation being obtained according to a solution-diffusion mechanism. Higher fluxes could be achieved when the local pressure on the feed side is maintained as close as possible to the local saturation pressure. The permeate partial pressure is guaranteed by vacuum or using an inert sweep gas (see Figure 1). To prevent condensation, it is possible to exploit a slightly superheated vapor, even if, under this condition, the flux could decrease. However, the membrane could be placed vertically thus, in case of condensation, the condensate does not accumulate on the membrane surface, rather it flows downwards to the bottom of the unit. The membrane is not in contact with the reaction mixture rather, in a single unit, it is in the head space of the reactor. This could also ensure a longer membrane lifetime [38].

It is not easy to carry out a direct comparison between VP and PV efficiency; however, VP, similar to gas separation, could exhibit some advantages over PV [9]. For example, the evaporation energy could be supplied in a separate evaporator thus avoiding the use of heat exchangers. Then, a more favorable fluid dynamics allows the use of larger modules with consequent benefits in terms of cost reduction. The advantages of VP are evident when the feed solution contains non-volatile or undissolved species. Some studies show that VP increases the permselectivity of water more than PV, as proved by the higher concentration of water present in the permeate [39], as well as higher fluxes being obtained under specific conditions [40]. Anyhow the flux could decrease when highly swollen membranes are used, such membranes favoring the PV process [41]. The volumetric flow rate is about 400 times higher for a vapor than a liquid feed at a specific mass flow rate and equivalent temperature and pressure conditions. For this reason, a lower membrane area is required, also avoiding severe chemical reaction conditions and the damage of the membrane generally caused by impurities present in the feed [38]. The membrane flux "J" represents the performance of the membrane

$$
\mathrm{J}=\mathrm{P} \times \Delta \mathrm{P} / 1
$$

considering " $\mathrm{P}$ " as the permeability coefficient for a vapor, " $\Delta \mathrm{P}$ " the difference in pressure between feed and permeate, while " 1 " is the thickness of the membrane. The processes which have been improved by integrating a VP unit are mainly natural gas or organic solvents dehydration as well as water separation from air and its recovery from the waste stream.

\section{Membrane Reactors and Process Configurations}

Some important reviews concerning the types of membrane, reactor configuration and modeling [21,35,42-49], specific applications, and hybrid processes realized on an industrial scale [50] have been published $[1,9,21,41-43,47,51-56]$. In a hybrid process, several possibilities exist to implement the PV or VP modules and the membrane separation devices and the reactor can be separated into two units or integrated into a single one [53,55]. In Figure 2 some conceptual processes from the literature are shown $[53,56]$. The stirred batch reactor is the most commonly used for PV and VP studies. When it is combined with an external separation unit (Figure 2a, recycle tank reactor, $\mathrm{TR}+\mathrm{PV}$ or $\mathrm{TR}+\mathrm{VP}$ ), the stream leaving the catalytic reactor (liquid or vapor in the case of PV or 
VP respectively), constituted by the non-converted reactants and the products, passes through the membrane for the selective removal of product or byproduct and the retentate returns to the reactor with some advantages in the case of low permeability membranes or for fast reactions. In this case, two membrane modules could be put in, making the clean-up or regeneration steps easier and, if a membrane fails, the chemical reactor can be maintained in operation in combination with the second one. Moreover, by using this configuration [57], it is possible to optimize independently both the selective and the catalytic properties. Instead, in the case the reactor and separation are integrated in one single unit (Figure 2b, TRPV or TRVP), the membrane is placed into the stirred reactor, in a flat or tubular configuration. This integration may offer major benefits such as process efficiency and compactness along with flexibility due to its modular design, with consequent reduction in energy input, capital investment, and process costs. Moreover, these reactive separation technologies could be improved by heat-integration, and the use of solid catalysts could avoid the conventional operations related to homogeneous catalysis, with consequent advantages in the efficient use of raw materials and reaction volume and, at the same time, enhanced conversion and selectivity values [4]. Usually, the batch processes are more advantageous when a variety of different products are produced in relatively small volumes using the same equipment, whereas continuous processes are employed for large volume products since these processes are less labor intensive. In the recycle continuous stirred tank reactor (CSTR) both feed and retentate streams are added to the configuration in order to obtain products continuously. Also in this case, the membrane could be external (Figure 2c) or internal (Figure 2d) to the reactor. Then, the same situation could be proposed in the case of the plug flow reactor (PFR), even if the membrane and reactor are more frequently combined in a single unit (Figure 2e,f).

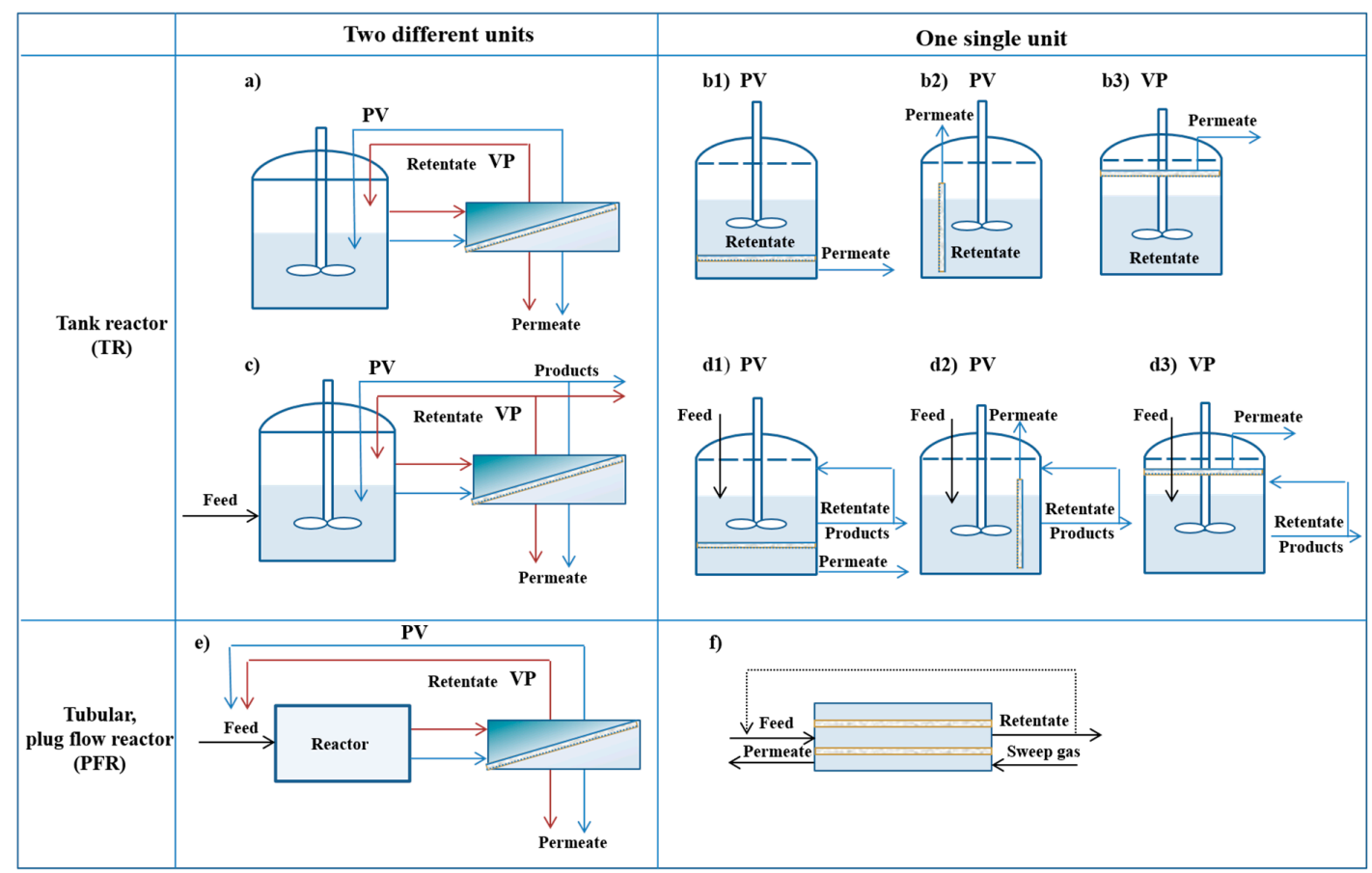

Figure 2. Examples of reactor-membrane separator configurations. TR with external separation unit, TR+PV or TR+VP (a); TR with internal flat membrane in PV mode, TRPV (b1), or VP mode TRVP (b3) and tubular membrane, TRPV (b2); (c) recycle continuous stirred tank reactor (CSTR) with external separation unit, CST+PV or CST+VP (c), or internal unit, CSTPV or CSTVP (d1-d3); PFR with external separation unit, PFR+VP or PFR+PV (e) or internal unit, PRFVP (f).

A very relevant application of hybrid reactor-membrane configurations is also demonstrated by the patented PermSMBR process, as a very promising technology for the synthesis of oxyfuels 
as ethers, acetals, and esters [13-16,20]. The process integrates the use of permselective membranes with the technology based on the simulated moving bed reactor (SMBR), advantageously applied for reactive separation processes. SMBR consists of a set of columns packed with a catalyst characterized by adsorptive properties or with a mixture of adsorbent particles and a solid catalyst, so as to combine the chemical reaction with continuous countercurrent chromatographic separation. Specifically, SMBR comprises two inlet streams of feed and desorbent and two outlet streams of extract and raffinate. If the feed comprises two compounds $\mathrm{A}$ and $\mathrm{B}$ reacting to give two products $\mathrm{C}$ and $\mathrm{D}$, with different adsorptive properties, then a mixture of a reactant and a product is obtained as the extract and a mixture as the raffinate. The standard SMBR configuration, however, suffers from some drawbacks, like products dilution with the desorbent and the need of pure raw materials to avoid the deactivation of catalyst and/or adsorbent. So, in the novel PermSMBR approach each column contains a set of membranes with the catalyst/adsorbent packed inside/outside the membranes. Then, the permeate is collected from each column and the product is removed not only by adsorption but also through the membranes, leading to higher productivity and lower desorbing consumption. On the whole, PermSMBR appears as a competitive technology if compared with other intensified processes, allowing reduced solvent consumption and lower costs associated with the separation units, providing complete conversion of reactants and high purity and productivity of the desired product.

\section{Membranes}

The mass transport in PV and VP processes is based on compound-membrane interactions and, therefore, the chemical nature and the physical properties of the membrane material are key factors for the attainment of the separation process. Specifically, successful PV and VP applications require membranes with adequate properties in terms of selectivity (separation ability) or mass transfer rate (permeate flux) across them, productivity (amount of a species permeating across a specific area of membrane in a specific unit time, depending on the membrane's intrinsic permeability and thickness) and stability. Such membrane properties must be combined with creative engineering solutions and innovative design of the experimental setup or industrial pilot plant. Therefore, the fundamental criteria for selecting materials suitable in PV and VP processes are high chemical and mechanical resistance to guarantee long-term stability and life, excellent permeability and sorption capacity, and preferential transport of the target compound to ensure high performance. Thermal properties are also important considering that high temperature could be used to favor the permeation of the target species across the membrane [30]. Since the type of membrane employed influences the VP and PV processes efficiency, each reaction should be considered as an independent case [35].

Hydrophilic membranes were the first to achieve industrial applications and were used above all for organic solvent dehydration [1]. However, nowadays, there are many studies dealing with research and development of hydrophilic membranes, which are cataloged as organic, inorganic, and organic-inorganic hybrid membranes. Specifically, hydrophilic organic polymers are mostly applied exploiting the interaction of water with groups present in the polymeric chain. Examples are cellulose acetate, polyvinyl alcohol (PVA), polyimides, polymaleimides, Nafion, and polyacrylonitrile (PAN) [38]. PVA, in fact, is a hydrophilic polymer with exceptional water permeability, high abrasion resistance, and excellent mechanical properties. Its critical issue could be its high degree of swelling in the presence of water which reduces significantly its selectivity and stability. Anyhow, the cross-linking procedure of PVA allows attainment of high hydrophilicity and stability under acidic environment. Sulzer Chemtech fabricated a wide range of composite membranes (Pervap ${ }^{\circledR}$ ) consisting of a thin separative layer made of cross-linked PVA supported on a porous layer, such as polyacrilonitrile on a nonwoven fabric.

Under some PV and VP conditions, inorganic membranes are more efficient than organic ones thanks to their chemical, mechanical, and thermal stability. Among them, some progress in zeolite materials has been made due to their high tailoring character, in terms of chemical properties, pore size, adsorption capacity, shape selectivity, and stability [1,49]. At high temperatures, silica-rich zeolites, 
such as faujasites, phillipsite or mordenite could be considered more suitable, even if their use is still limited by definition of proper preparation methods, which enable reproducible and long-term resistant materials to be obtained. A large variety of zeolites with pore size of a few angstroms is available and type A zeolites, containing cations like K (zeolite 3A), Na (zeolite 4A) or Ca (zeolite 5A), result in highly hydrophilic materials. For example, many papers show that zeolite $\mathrm{NaA}$ membrane is a promising candidate for in situ water separation in an extractor-type catalytic membrane reactor (CMR). It could be used for alcohol dehydration catalyzed by ion-exchange acid resins, which is generally limited by deactivation of the catalyst because of the water adsorption on the resin active sites. Specifically, such well-established capability of NaA zeolite membranes towards selective water separation was exploited in the first industrial application of zeolite membranes for de-watering of ethanol and isopropanol [58]. Such a membrane was characterized by high water-selective permeation at all the ethanol concentrations, with a separation factor $>5000$ and a water permeation flux $>2 \mathrm{~kg} / \mathrm{m}^{2} / \mathrm{h}$ [59]. On the other hand, the NaA membranes suffer from three main drawbacks: (1) dealumination under strong acidic environment limits its use only in media with $\mathrm{pH}>6$; (2) the large amount of $\mathrm{Al}$ present in the framework structure could cause membrane shrinkage and (3) the scale-up of the hydrothermal synthesis is difficult because of formation of large intercrystalline defects in the active layer [29]. By increasing the alumina content, the permselectivity increased too, reaching a constant value at $>70 \mathrm{wt} \% \mathrm{Al}_{2} \mathrm{O}_{3}$. Membranes, like ZSM- 5 and $\mathrm{T}$ zeolite, are also good candidates for dehydration purposes, due to their uniform pore size distribution and high hydrophilicity [60]. Highly water-selective mordenite membranes resulted in achieving a separation factor more than 250 for the separation of water-acetic acid solutions [61]. The reproducible preparation of defect-free membranes is still challenging although different synthesis methods, like secondary growth, have been developed to improve membrane quality [62]. Additionally, zeolite membrane preparation methods are still carried out batch-wise whereas continuous methods are needed in order to scale-up production [63].

A novel research trend concerns the development of mixed matrix membranes (MMMs) characterized by nanoporous zeolite frameworks combined with organic polymer matrices. Deng et al. [64] developed a process to produce a high-quality MMM by mixing a nanoporous zeolite imidazole framework (ZIF-8) with PVA dispersed in aqueous solution. This MMM was characterized by enhanced permeability owing to an increased fractional free volume in the membrane, suitable for ethanol dehydration by pervaporation.

The zeolite-based membranes can be affected by impurity adsorption from the reaction medium or from the atmosphere during their storage with consequent negative effects on permeation and separation performance. At the same time, also some species of the mixture could be strongly adsorbed into the zeolite pores thus further restricting the permeation of other species [35]. However, it is important to consider the durability of membrane materials under severe reaction conditions. Usually a recycle stream of the retentate is a pre-requisite for the process, because in most cases a single pass would not be sufficient to obtain both a high purity retentate and permeate, not even at optimized process conditions. So, VP could be a preferable alternative compared to PV because high boiling inorganic acids and impurities remain in the liquid phase and do not affect the sensitive membrane material. This could lead to a longer life-time of the membrane, with advantages from an economic point of view.

Organophilic and organoselective membranes are also employed for organic separation from water streams, mainly for wastewater treatment and recycling of organics in industrial applications. Organic-inorganic hybrid materials have been proposed as the best solution for exploiting concurrently the functionality and the stability of the organic and inorganic fraction respectively.

Moreover, bifunctional membranes, combining catalytic and separation roles (Figure 3) have been also proposed. The material can be very different, ranging from zeolite to polymeric systems treated by cross-linking with acid groups [65]. Even if the catalyst loading present on the membrane surface may be lower than that employed in conventional catalytic tests, it is possible to observe higher water 
permeation in the CMR since water is formed directly in the membrane, and this generates a higher water driving force.

Recently, multilayer assembling as layer-by-layer thin films was also proposed as a novel approach for coating substrates with functional thin films. A charged material is adsorbed onto a substrate and then layered with another material characterized by an opposite charge, so forming a bilayer with a thickness of a few nanometers, on which other layers can be charged. The substrate can be eventually removed, yielding macroscopic films, suitable as effective membranes [66].

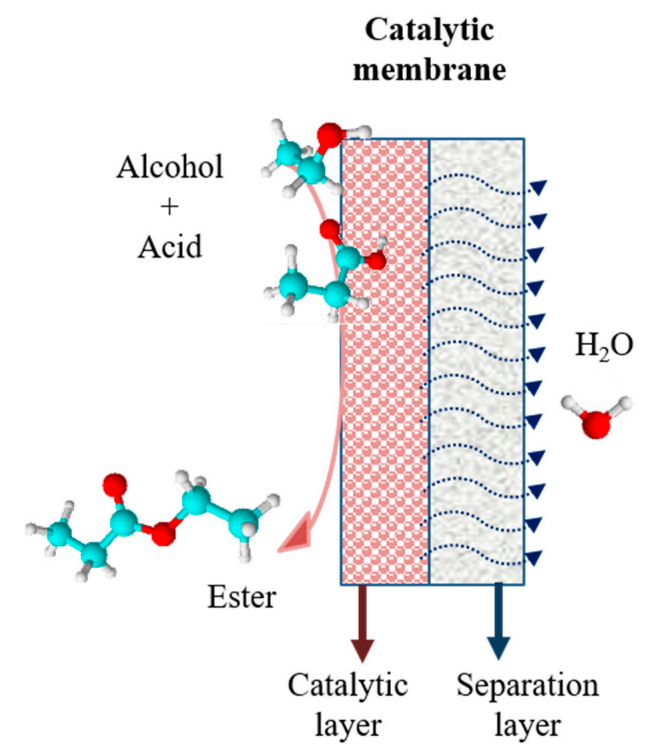

Figure 3. Catalytic membrane.

\section{PV and VP Applications}

The typical applications for PV and VP can be classified into various classes: (i) organic solvents dehydration; (ii) organics removal from aqueous solutions; (iii) separation of anhydrous organic mixtures; (iv) concentration of aqueous solutions. Moreover, they are suitable also for separation of heat sensitive products. Specifically, based on the number of installations along with the area of the membrane used and the economic advantages, the most important PV and VP applications are water removal from organic solvents and solvent mixtures. The development of membrane units and process know-how allows the installation of industrial plants with large capacities. Additionally, one of the main growing sectors is the separation of organics. Membranes have been developed and tested also at industrial scale, such as for the methanol recovery in the mono-tert-butylether synthesis or for the benzene concentration reduction in gasoline [34].

\subsection{Model Reactions in PV Assisted Processes}

The first pervaporation-based hybrid process was developed by Binning and James (1958) at American Oil for the dehydration of isopropanol-ethanol mixtures using a PV-distillation system. Nevertheless, the lack of methodology to synthesize a resistant and active membrane made its marketing difficult. Only after the 1980s, was pervaporation considered an attractive alternative for other separation processes and membrane technology began to be developed to make PV technology commercially viable.

The reactions here reviewed are based on PV-aided processes, for which industrial scale application is still limited, as for example the esterification of carboxylic acids. Among reversible reactions, controlled by thermodynamic equilibrium, esterification is the reaction between a carboxylic acid and an alcohol with formation of an ester and water as byproduct (Equation (1)): 


$$
\mathrm{R}_{1} \mathrm{COOH}+\mathrm{R}_{2} \mathrm{OH} \leftrightarrows \mathrm{R}_{1} \mathrm{COOR}_{2}+\mathrm{H}_{2} \mathrm{O}
$$

\section{Carboxylic acid Alcohol Ester Water}

Up to today, in PV-esterification coupling systems, several types of commercial membranes have been used [50], including PERVATECH BV [13-20], GFT-1005 [67], polydimethylsiloxane [68], PERVAP 2201 [69] and PERVAP 1005 [70] for the synthesis of esters, such as alkyl and benzyl acetates or lactates, etc. Some examples are reported here and continued in Table 3.

Table 3. PV and VP process examples.

\begin{tabular}{|c|c|c|c|c|}
\hline Membrane & Nature of Membrane & Reaction Studied & Technology * & Reference \\
\hline Zeolite T & Zeolite membrane & Esterification lactic acid + ethanol & TRVP & [11] \\
\hline Pervatech BV & $\begin{array}{l}\text { Microporous silica } \\
\text { membrane }\end{array}$ & $\begin{array}{c}\text { Esterification lactic acid }+ \text { ethanol } \\
\text { Acetalization acetaldehyde }+ \\
\text { ethanol (additive) }\end{array}$ & PermSMBR & [13] \\
\hline Pervatech BV & $\begin{array}{l}\text { Microporous silica } \\
\text { membrane }\end{array}$ & $\begin{array}{l}\text { Acetalization acetaldehyde }+ \\
\text { butanol (additive) }\end{array}$ & PermSMBR & {$[14,15]$} \\
\hline Pervatech BV & $\begin{array}{l}\text { Microporous silica } \\
\text { membrane }\end{array}$ & $\begin{array}{l}\text { Acetalization butyraldehyde + } \\
\text { ethanol (additive) }\end{array}$ & PermSMBR & [16] \\
\hline Pervatech BV & $\begin{array}{l}\text { Microporous silica } \\
\text { membrane }\end{array}$ & Dehydration $n$-butanol & $\mathrm{SMBR}+\mathrm{PV}$ & [18] \\
\hline $\mathrm{NaA}$ & $\begin{array}{l}\text { Catalytic zeolite } \\
\text { membrane }\end{array}$ & $\begin{array}{l}\text { Etherification of } n \text {-pentanol } \\
\quad \text { (blending additive) }\end{array}$ & $\begin{array}{l}\text { ExtractorCMR }{ }^{+} \\
\mathrm{ZCMR}^{++}\end{array}$ & [29] \\
\hline GFT-1005 membrane & $\begin{array}{l}\text { organic acid-compatible } \\
\text { PVA-based membrane }\end{array}$ & Esterification lactic acid + ethanol & $\mathrm{TR}+\mathrm{PV}$ & [36] \\
\hline $\begin{array}{l}\text { Mordenite } \\
\text { membrane }\end{array}$ & Catalytic membrane & Dehydration of acetic acid & TRPV & [61] \\
\hline Pervap 2200 & $\begin{array}{l}\text { Hydrophilic polymeric } \\
\text { membrane }\end{array}$ & $\begin{array}{l}\text { Enzymatic esterification glucose }+ \\
\text { fatty acids }\end{array}$ & TRVP & [65] \\
\hline PERVAP GFT-1005 & $\begin{array}{l}\text { Hydrophilic polymeric } \\
\text { membrane }\end{array}$ & Esterification acetic acid + ethanol & PVMR & [67] \\
\hline PDMS & $\begin{array}{l}\text { Hydrophobic cross-linked } \\
\text { membrane }\end{array}$ & Esterification acetic acid + ethanol & TRPV & [68] \\
\hline PERVAP 2201 & $\begin{array}{l}\text { Hydrophilic polymeric } \\
\text { membrane }\end{array}$ & $\begin{array}{l}\text { Esterification acetic acid + } \\
\text { isopropanol }\end{array}$ & PVMR & [69] \\
\hline PERVAP GFT-1005 & $\begin{array}{l}\text { PVA polymeric membrane } \\
\text { supported on } \\
\text { polyacrylonitrile layered } \\
\text { onto cellulose material }\end{array}$ & $\begin{array}{l}\text { Esterification acetic acid + } \\
\text { benzyl alcohol }\end{array}$ & TRPV & {$[70,71]$} \\
\hline MER, PHI, CHA & $\begin{array}{l}\text { Acid-tolerant hydrophilic } \\
\text { zeolite membrane }\end{array}$ & $\begin{array}{c}\text { Ester condensation between } \\
\text { various kinds of carboxylic and } \\
\text { alcohols at }<50{ }^{\circ} \mathrm{C}\end{array}$ & TRPV & [72] \\
\hline $\begin{array}{l}\text { Mordenite } / \alpha-\mathrm{Al}_{2} \mathrm{O}_{3} \\
\text { Zeolite } \mathrm{A} / \alpha-\mathrm{Al}_{2} \mathrm{O}_{3}\end{array}$ & Zeolite membrane & Esterification acetic acid + ethanol & PFRPV & [73] \\
\hline Zeolite T & Zeolitic membrane & Esterification acetic acid+ ethanol & TRPV & {$[74,75]$} \\
\hline $\begin{array}{c}\text { Polyetherimid } \\
\text { based membrane }\end{array}$ & $\begin{array}{l}\text { Polymeric/ceramic } \\
\text { membrane }\end{array}$ & Esterification acetic acid + ethanol & PFRPV & {$[76,77]$} \\
\hline $\begin{array}{l}\text { PVA/ceramic } \\
\text { composite }\end{array}$ & $\begin{array}{l}\text { Hydrophilic polymeric } \\
\text { membrane }\end{array}$ & $\begin{array}{l}\text { Esterification acetic acid }+ \\
n \text {-butanol }\end{array}$ & TRPV & {$[78,79]$} \\
\hline SOD & $\begin{array}{l}\text { Tubular hydroxyl sodalite } \\
\text { membrane }\end{array}$ & $\begin{array}{c}\text { Esterification acetic acid + } \\
\text { 1-butanol }\end{array}$ & $\mathrm{TR}+\mathrm{PV}$ & {$[80,81]$} \\
\hline $\mathrm{H}-\mathrm{ZSM}-5 / \alpha-\mathrm{Al}_{2} \mathrm{O}_{3}$ & Zeolite catalytic membrane & Esterification acetic acid + ethanol & $\begin{array}{c}\text { PFRPV } \\
\text { ZMR }^{++} \\
\text {AZMR }^{++++}\end{array}$ & [82-88] \\
\hline H-USY/TNO-TPD & $\begin{array}{l}\text { Composite catalytic } \\
\text { membrane: zeolite coating } \\
\text { on top of ceramic hollow } \\
\text { fiber silica membrane }\end{array}$ & Esterification acetic acid + butanol & CMR & [89] \\
\hline
\end{tabular}


Table 3. Cont.

\begin{tabular}{|c|c|c|c|c|}
\hline Membrane & Nature of Membrane & Reaction Studied & Technology * & Reference \\
\hline H-ZSM-5/mordenite & $\begin{array}{l}\text { Bi-functional zeolite } \\
\text { membrane }\end{array}$ & Esterification acetic acid + ethanol & CMR & [90-92] \\
\hline $\begin{array}{l}\text { PVA/PES + catalytic } \\
\text { PVA/PES }\end{array}$ & $\begin{array}{l}\text { Catalytically active } \\
\text { membrane Support layer: } \\
\text { PES porous membrane; } \\
\text { separation layer: PVA } \\
\text { membrane; porous } \\
\text { catalytic layer }\end{array}$ & $\begin{array}{l}\text { Esterification acetic acid }+ \\
n \text {-butanol }\end{array}$ & TR-CMR & {$[93,94]$} \\
\hline Sulzer Pervap 2001 & $\begin{array}{l}\text { Hydrophilic polymeric } \\
\text { membrane }\end{array}$ & $\begin{array}{l}\text { Enzymatic esterification glycerol + } \\
\text { stearic acid }\end{array}$ & $\mathrm{TR}+\mathrm{PV}$ & [95] \\
\hline Ultem & Polyimide membrane & $\begin{array}{l}\text { Esterification oleic acid + ethanol } \\
\text { (biodiesel) }\end{array}$ & TRVP & [96-98] \\
\hline $\mathrm{NaA}$ & $\begin{array}{l}\text { Tubular nanoporous } \\
\text { zeolite membrane }\end{array}$ & $\begin{array}{l}\text { Esterification of propionic acid }+ \\
\text { isopropanol }\end{array}$ & $\mathrm{SB}+\mathrm{VP}$ & {$[99,100]$} \\
\hline $\begin{array}{l}\mathrm{NaA} / \text { carbon-zirconia } \\
\text { support }\end{array}$ & $\begin{array}{l}\text { Tubular zeolite layer on } \\
\text { porous } \alpha-\mathrm{Al}_{2} \mathrm{O}_{3} \text { tube }\end{array}$ & Esterification lactic acid + ethanol & $\begin{array}{l}\text { TRVP } \\
\text { TRPV }\end{array}$ & [101] \\
\hline $\mathrm{CHA}$ & $\begin{array}{l}\text { Polycrystalline zeolite } \\
\text { membrane }\end{array}$ & $\begin{array}{l}\text { Esterification of adipic acid + } \\
\text { isopropyl alcohol }\end{array}$ & TRVP & [102] \\
\hline $\mathrm{Zr}\left(\mathrm{SO}_{4}\right)_{3} \cdot 4 \mathrm{H}_{2} \mathrm{O} /$ chitosan & Catalytic membrane & $\begin{array}{l}\text { Esterification glycerol + acetic } \\
\text { acid (additive) }\end{array}$ & TRPV(CMR) & {$[22,103,104]$} \\
\hline PVA & $\begin{array}{l}\text { Hydrophilic polymeric } \\
\text { membrane }\end{array}$ & $\begin{array}{l}\text { Esterification acetic acid }+ \\
\text { methanol }\end{array}$ & $\begin{array}{l}\text { SBPV } \\
\text { PFRPV } \\
\text { CSTPV }\end{array}$ & [105-112] \\
\hline PEI-POPMI & $\begin{array}{l}\text { Aromatic polyimide } \\
\text { hollow fiber }\end{array}$ & $\begin{array}{l}\text { Esterification oleic acid + } \\
\text { ethanol (biodiesel) }\end{array}$ & TRPV & [113] \\
\hline PVA/PES substrate & $\begin{array}{l}\text { Composite hydrophilic } \\
\text { polymeric membrane }\end{array}$ & $\begin{array}{l}\text { Esterification oleic acid }+ \\
\text { methanol (biodiesel) }\end{array}$ & TRPV & [114] \\
\hline PERVAP 1000 & $\begin{array}{l}\text { Crosslinked PVA layer } \\
\text { coated onto a PAN } \\
\text { substrate }\end{array}$ & $\begin{array}{l}\text { Esterification oleic acid + } \\
\text { ethanol (biodiesel) }\end{array}$ & $\mathrm{TR}+\mathrm{PV}$ & [115] \\
\hline PEI-POPMI & $\begin{array}{l}\text { Aromatic polyimide } \\
\text { hollow fiber }\end{array}$ & $\begin{array}{l}\text { Esterification oleic acid + } \\
\text { ethanol (biodiesel) }\end{array}$ & TRVP & {$[116,117]$} \\
\hline $\begin{array}{l}\text { PERVAP } 2201 \\
\text { PERVAP } 2202 \\
\text { CMC-VP-43 }\end{array}$ & $\begin{array}{l}\text { Hydrophilic polymeric } \\
\text { membrane }\end{array}$ & $\begin{array}{l}\text { Enzymatic esterification fusel oil + } \\
\text { oleic acid (biolubricant) }\end{array}$ & $\mathrm{TR}+\mathrm{PV}$ & [118] \\
\hline PERVAP-1005 & $\begin{array}{l}\text { Hydrophilic polymeric } \\
\text { membrane }\end{array}$ & $\begin{array}{l}\text { Enzymatic esterification of oleic } \\
\text { acid }+i \text {-amyl alcohol } \\
\text { (bio-lubricant) }\end{array}$ & $\mathrm{TR}+\mathrm{PV}$ & {$[119-121]$} \\
\hline $\begin{array}{c}\mathrm{MOR} / \mathrm{ZSM} 5 / \mathrm{CHA} \\
\mathrm{NaA}\end{array}$ & Zeolite tubular membrane & $\begin{array}{c}\text { Etherification methanol + } \\
\text { tert-butyl alcohol } \\
\text { (oxygenate additive) }\end{array}$ & $\mathrm{ZCMR}^{+++\dagger}$ & [122] \\
\hline PVA & $\begin{array}{l}\text { Hydrophilic polymeric } \\
\text { membrane }\end{array}$ & $\begin{array}{c}\text { Enzymatic etherification ethanol + } \\
\text { tert-butyl alcohol } \\
\text { (oxygenate additive) }\end{array}$ & $\begin{array}{l}\text { SBPV } \\
\text { PFRPV } \\
\text { CSTPV }\end{array}$ & {$[123-125]$} \\
\hline HybSi (ENC) & $\begin{array}{l}\text { Inorganic/organic hybrid } \\
\text { membrane }\end{array}$ & $\begin{array}{l}\text { Esterification bioethanol + } \\
\text { butanal (additive) }\end{array}$ & SBPV & [126] \\
\hline HybSi & $\begin{array}{l}\gamma-\mathrm{Al}_{2} \mathrm{O}_{3} \text { tubular phase } \\
\text { coated with organic } \\
\text { polymer }\end{array}$ & $\begin{array}{l}\text { Etherification glycerol + tert-butyl } \\
\text { alcohol (additive) }\end{array}$ & $\mathrm{TR}+\mathrm{VP}$ & [127-132] \\
\hline HybSi & $\begin{array}{c}\gamma-\mathrm{Al}_{2} \mathrm{O}_{3} \text { tubular phase } \\
\text { coated with organic } \\
\text { polymer }\end{array}$ & $\begin{array}{l}\text { Etherification glycerol + } \\
\text { butanol (additive) }\end{array}$ & $\mathrm{TR}+\mathrm{VP}$ & [133] \\
\hline
\end{tabular}

* Technology: CMR = Catalytic Membrane reactor; CSTPV = Continuous Stirred Tank reactor with internal PV separation unit; SB+PV = Semi Batch reactor with external PV separation unit; SBPV = Semi Batch reactor with internal PV separation unit; PermSMBR = combination of SMBR with membranes (PV or VP); PFRPV = Plug Flow Reactor with internal PV separation unit; PVMR = PV Membrane Reactor; SMBR = Simulated Moving Bed Reactor; TR = Tank Reactor; TRPV = Tank Reactor with internal PV separation unit; TRVP = Tank Reactor with internal VP separation unit; TR+PV $=$ Tank Reactor with external PV separation unit; ${ }^{\dagger}$ Extractor-CMR = zeolite NaA membrane with an ion-exchange resin in an extractor type CMR configuration; ${ }^{+\dagger} \mathrm{ZCMR}=$ Zeolite Catalytic Membrane Reactor; ${ }^{++\dagger} \mathrm{ZMR}=$ Zeolite Membrane Reactor with the H-ZSM5 catalyst packed as powder inside a tubular Na-ZSM-5 membrane; ${ }^{++++}$AZMR = only H-ZSM-5 as membrane and catalysts. 
By investigating the esterification reaction of acetic acid with ethanol combined with PV process, a simple, three-parameter model describing the concentration profiles in the process was developed [67]. The cross-linking treatment of the PVA membrane was exploited to avoid the modification of the alcoholic groups present on the surface membrane by esterification with consequent reduction of its separative properties [53]. However, as previously mentioned, compared to polymeric material, inorganic membranes usually are characterized by superior chemical and thermal stability, even if today only a very few industrial processes based on inorganic membranes can be found, e.g., drinking and waste water treatment, separation in organic media and purification of used oil [71]. Hence, the use of inorganic membranes has been encouraged: specifically zeolite membranes based on merlinoite (MER) and chabazite (CHA) possess high separation factors $(>500)$ and water fluxes in both PV and VP aided esterification [72]. De la Iglesia et al. [73], for example, used membranes based on mordenite and zeolite A in a continuous membrane reactor and Amberlyst as catalysts for the esterification of ethanol and acetic acid. The mordenite membrane exhibited a good stability under the conditions considered, with a conversion of $90 \%$ for 5 days, whereas with zeolite $\mathrm{A}$, the conversion decreased from $72 \%$ to $53 \%$ after two days of reaction.

Tanaka et al. reported that T-type zeolite membrane showed high PV performance for water-organic liquid mixtures as well as good stability to acid solutions and it was then employed for the PV-aided esterification of acetic acid with ethanol [74]. The zeolite membrane was grown hydrothermally on the surface of a porous cylindrical alumina support and the catalyst used was Amberlyst-15, kept in the reactor under stirring at $70{ }^{\circ} \mathrm{C}$. By using a molar ratio between alcohol and acetic acid of 1.5 or 2, the conversion was complete within $8 \mathrm{~h}$. A kinetic modeling of propionic acid esterification with ethanol aided by PV employing a T-zeolite membrane has been developed and compared with the experimental data in an attempt to shed light on the effects of the operating parameters: temperature, ethanol/acid molar ratio, as well as the ratio of membrane area to amount of initial reaction liquid [75]. The use of a membrane with a larger area improved the water removal and thus the esterification conversion could be ensured despite higher equipment costs.

A model of a PV membrane reactor was presented by Zhu et al. [76], giving a reasonable fit for a set of experimental data obtained in the esterification of acetic acid with ethanol performed in a PFRPV equipped with a polymeric/ceramic composite membrane based on poly-etherimide (PEI). Also in this case, the conversion was higher than the calculated equilibrium values for a specific range of experimental parameters.

In most PV-coupled esterification studies, the membranes employed are inactive from a catalytic point of view and they are used in a batch configuration $[36,54,67,70,74,76-81]$ or placed in a recycle loop $[36,67,70,77,82]$. However, many other authors have developed membranes characterized by the selective layer with catalytic functionality, thus offering important advantages compared to conventional reactor set-up: this configuration may be considered promising to overcome the typical limits of catalytic reactors [57,83-90]. Bernal et al. [88] for example employed, for the first time, the H-ZSM5 zeolite membrane reactors (ZMR) in the continuous esterification of acetic acid with ethanol, by exploiting the lower diffusion resistance which a hybrid catalytic membrane reactor could offer assuring the immediate removal of the formed products and giving rise to higher turnover.

Peters et al. [89] used catalytically active H-USY zeolite-based membranes to perform the continuous esterification of acetic acid with butanol: thanks to the optimization of the catalytic layer and the coupling of the reaction with the separation function, the reactor performance was enhanced. The catalytic functionality of H-ZSM5 was integrated with the selective water separation properties of mordenite membranes by De la Iglesia et al. [90], who developed two-layered mordenite-ZSM5 bi-functional membranes. Such a system was exploited in the esterification reaction of acetic acid with ethanol and the simultaneous control of the membrane thickness and zeolite membrane composition further improved the reaction performance [91]. By using this approach, no additional catalyst neutralization step or recovery, which is normally needed with a homogeneous catalyst, is required. 
When the selective and catalytic functions are integrated into one single layer, specific material properties are required: in fact, to attain high water selectivity, the diffusion of all components except water through the catalytic membrane should be low, while for an efficient use of the catalyst, high diffusion of the reactants is required. In the esterification reaction of an acid with an alcohol, for example, the reactants diffuse into the catalytic layer to be converted to ester and water (see Figure 3); then the ester returns to the liquid mixture whereas the water is removed in situ. Consequently, the hydrolysis of the ester is limited while the conversion is enhanced compared to the values obtained using a non-catalytic MR $[88,92,93]$. On account of this, Zhang et al. employed a catalytically active $\mathrm{PV}$ membrane to improve the conversion of acetic acid in the esterification reaction with $n$-butanol. The membrane was synthesized by coating a porous catalytic layer containing polyvinyl alcohol and ion-exchange resins on a dense polyvinyl alcohol (PVA)/polyethersulfone (PES) separation membrane. Although the coating of a catalytic layer on the separation layer would enhance the permeability but, at the same time, limit the selectivity of the catalytically active membrane, the system was active both from a catalytic and a separation functionality point of view. In fact, the conversion of acetic acid reached a value of $91.4 \%$ in $20 \mathrm{~h}$ at $85{ }^{\circ} \mathrm{C}$ with an enhancement of about $27 \%$, considering that, with this condition, the equilibrium conversion is only $71.9 \%$ [94].

Esterification reactions, also enzyme-catalyzed esterification reactions (specifically, the lipase) have received great attention over the past decades due to the increasing demands for organic esters in biotechnology and the chemical industry: higher selectivity can be attained by the biotechnological way by exploiting milder reaction conditions [95]. Energy demand cost could be reduced and the conversion or yield of products enhanced. In this case, even if the water plays an important role being essential for lipase enzyme activation in its environment, excess water has a negative influence on enzyme activity and on substrate conversion. So, by eliminating the water from the reaction medium but keeping the system at constant water activity, it is possible to achieve higher productivity [30].

Inoue et al. [72] studied the water removal from organic aqueous solutions (equimolar mixture of water, ethanol, acetic acid. and ethyl acetate) by using MER, CHA. and PHI (phillipsite) zeolite membranes in the PV process. These membranes, characterized by acid-tolerant hydrophilic properties, were employed to perform stoichiometric ester condensation reactions close to room temperature $(<50$ $\left.{ }^{\circ} \mathrm{C}\right)$. They showed excellent water permselectivity, even with coexistence of methanol: the ester yields exceeded by more than $20 \%$ that of the equilibrium values [72].

\subsection{Model Reactions in VP Assisted Processes}

One of first papers regarding gas separation in the esterification of carboxylic acids with alcohols was published in 1987 by Kita et al. [96] who demonstrated that by selecting suitable permeation conditions total conversion could be achieved, by overcoming the equilibrium limits. Specifically the reaction between oleic acid and ethanol was investigated by removing the water vapor from the gaseous mixture, using a polymeric/ceramic composite membrane tube placed on the top of a stirred batch vessel. Permeability, diffusivity, and solubility of water vapor in and through the polyimide films were evaluated at $50^{\circ} \mathrm{C}$ showing a high water vapor permeability in comparison with that of $\mathrm{H}_{2}$, likely due to large solubility coefficient of water vapor.

A membrane constituted by PVA was used in the lipase-catalyzed esterification reaction aided by the VP mode for glucose fatty acid ester production. Specifically the water was removed from the azeotropic mixture constituted by the solvents used (ethyl methyl ketone and hexane) and a yield of $93 \%$ was obtained for glucose stearate after $48 \mathrm{~h}$ by employing an equimolar ratio of reactants [65].

By exploiting the very high permeation flux, water affinity, and selectivity of NaA zeolite membrane in VP configuration, it was possible to improve the esterification reaction performance $[97,98]$. Considering that such kinds of membranes show poor resistance under acidic conditions [21,99], they could not be easily applied in direct contact with acid. On the contrary, in PV mode some studies on the esterification of $i$-propyl propionate showed that $\mathrm{NaA}$ membrane allowed higher productivity to be obtained than with the PVA polymeric system (as PERVAP 2201) [100]. A tubular zeolite NaA 
membrane, prepared on a carbon/zirconia support, was also tested for the removal of water in the homogeneously catalyzed esterification of lactic acid with ethanol to produce ethyl lactate in both PV and VP mode. The reaction was studied in a batch reactor without catalyst and with $p$-toluene sulphonic acid as catalyst, the VP process giving a significantly enhanced yield [101]. Tanaka et al. applied T-type zeolite membrane to VP aided esterification of lactic acid with ethanol [11] finding that such a membrane has high permeation performance to water-organic liquid mixtures and good stability to acid solutions. The conversion value exceeded the equilibrium limit, reaching almost $100 \%$ within $8 \mathrm{~h}$ for ethanol/lactic acid molar ratio of 2.4 and 3.6. Hasegawa et al. [102] employed a zeolite membrane based on CHA in the VP for adipic acid esterification with isopropyl alcohol in presence of sulfuric acid as catalyst. The yield of di-isopropyl adipate reached $98 \%$, while the yield foreseen from equilibrium was $56 \%$.

\section{Biofuels and Fuel Additives Production Aided by PV or VP Processes}

\subsection{Biodiesel Production}

Biodiesel is a liquid fuel composed of long-chain fatty acid alkyl esters (FAAEs) obtained by transesterification of triacylglycerides (TGs) with an alcohol, generally methanol, with glycerol formation as by-product (Equation (2)) or by esterification of free fatty acids (FFAs) in the presence of an alcohol, as for example oleic acid and ethanol, leading to water as by-product (Equation (3)):

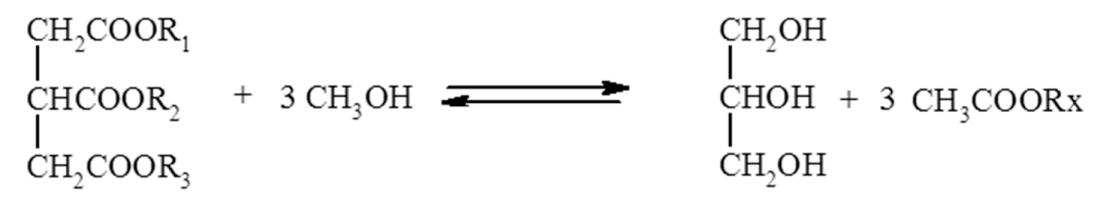

$\begin{array}{cccc}\text { Triacylglycerides } & \text { Methanol } & \text { Glycerol } & \text { Fatty acid methyl esters (FAMEs) } \\ \mathrm{CH}_{3}\left(\mathrm{CH}_{2}\right)_{7} \mathrm{CH}=\mathrm{CH}\left(\mathrm{CH}_{2}\right)_{7} \mathrm{COOH}+\mathrm{CH}_{3} \mathrm{CH}_{2} \mathrm{OH} \leftrightarrows \mathrm{CH}_{3}\left(\mathrm{CH}_{2}\right)_{7} \mathrm{CH}=\mathrm{CH}\left(\mathrm{CH}_{2}\right)_{7} \mathrm{COO} \cdot \mathrm{CH}_{2} \mathrm{CH}_{3}+\mathrm{H}_{2} \mathrm{O} & \text { (3) } \\ \text { Oleic acid } & \text { Ethanol } & \text { Ethyl oleate (FAEE) } & \text { Water }\end{array}$

Biodiesel represents an environmentally friendly, non-toxic, biodegradable and harmless fuel, free of sulfurous and aromatic compounds, the use of which reduces exhaust products achieving a high cetane number and ignition quality $[103,104]$. It could be used either as pure fuel or in blending with a conventional oil-derived fraction and be obtained in homogeneous, heterogeneous and enzymatic catalyzed processes, and also by supercritical technology $[105,106]$. These processes present some restrictions, such as the production of wastewater and high-energy consumption, with processing costs, feedstock availability, and environmental impacts being the main technical problems, which limit commercial use. In particular, many of the drawbacks of the industrial technology based on homogeneous catalysis are represented by the need for post-treatment, such as neutralization and washing steps with the production of organic solvents and water streams and, above all, the need for processing refined feedstocks to avoid the production of soaps due to the reaction of FFAs in the presence of basic catalyst (Equation (4)):

$$
\mathrm{R}_{1} \mathrm{COOH}+\mathrm{NaOH} \rightarrow \mathrm{R}_{1} \mathrm{COO}^{-} \mathrm{Na}^{+}+\mathrm{H}_{2} \mathrm{O}
$$

\section{FFA Sodium hydroxide Soap Water}

Moreover, since cheaper feedstocks such as non-refined oils, non-edible oils, and waste oils generally contain a high amount of FFAs, in order to convert them into FAAEs, the esterification reaction should be improved. Anyhow, the water produced in the ester synthesis (Equation (3)) inhibits the reaction because of thermodynamic constraints and catalyst deactivation and, at the same time, it could cause the esters to hydrolyze (Equation (5)), limiting the reaction efficiency [77]. On the 
whole, a concentration of water as low as $0.1 \mathrm{wt} \%$ in an oil source could strongly inhibit the conversion of oil to FAME during the transesterification reaction [107].

$$
\mathrm{R}_{1} \mathrm{COOR}_{2}+\mathrm{H}_{2} \mathrm{O} \leftrightarrows \mathrm{R}_{1} \mathrm{COOH}+\mathrm{R}_{2} \mathrm{OH}
$$

$$
\text { Alkyl ester (FAAE) Water FFA Alcohol }
$$

As previously mentioned, to drive the equilibrium towards ester formation, the employment of an excess of one reactant, generally alcohol, or the use of integrated units (reactive distillation, reactive absorption, reactive extraction, membrane reactors or centrifugal contact separations) for in situ removal of products have been exploited [22]. The use of a large excess of one reactant could cause inefficient exploitation of the reactor volume and a higher cost of subsequent separation steps to recover the reactant. As regards reactive separation processes for biodiesel production, an overview was provided by Kiss et al. [4], while the main applications of membrane technology for biodiesel production and refining technology were reviewed by Atadashi et al. [108] and Shuit et al. [109]. By comparing the energy requirements for a conventional two-step process based on FFAs pre-treatment and TGs transesterification (acid and basic catalysis respectively) with a reactive separations process, it is possible to verify that the specific energy use in reactive separation processes is significantly lower than that required for the FAAE purification step alone [3,4]. Over the last decades, great efforts have been undertaken in PV and VP processes applied both in transesterification and esterification reactions. In the first case, the reaction products (FAAEs and glycerol) and the catalyst are soluble in the alcoholic phase. Considering the molecular sizes, the methanol/FAME/glycerol phase selectively passes through the membrane into the permeate stream, while the larger oil droplets are retained [4]. The FAAE synthesized by employing the membrane reactor easily meets both the free and total glycerine ASTM standards, even when low-grade lipid feedstock is processed [110]. Anyhow, the interest is focused on a reaction in which water is produced, so the esterification of FFAs will be discussed here. Some examples of PV and VP aided reactions are reported in Table 3.

The ratio of water production over water removal represents one of the key factors for the PV-aided esterification performance, and the operating parameters which could affect this ratio can be divided into three groups: (i) all parameters influencing the esterification kinetics (e.g., catalyst concentration and molar ratio of reactants); (ii) parameters affecting the PV process, (e.g., ratio of membrane area to the reactor volume) and (iii) parameters which simultaneously influence both the esterification reaction kinetics and the PV process, e.g., temperature [111]. Another important parameter to be considered is the initial reactant molar ratio. In a recycle batch PV membrane reactor or a plug-flow PV membrane reactor, for example, it has been found that the optimal alcohol to acid initial molar ratio $\left(\mathrm{m}_{0}\right)$ is approximately 1.8 in the case of esterification of acetic acid and methanol using a PVA water selective membrane [112]. A higher initial ratio leads to a lower acid concentration and thus a decreased reaction rate. On the other hand, at a feed ratio lower than the optimal, the effect of alcohol loss through the membrane limits the productivity. The ratio of membrane area to reactor volume is important above all for batch processes, whereas, for a continuous process, the flow rate compared to the available membrane area should be considered as the determining factor.

In case of homogenous catalysis, the stability of the membrane is another decisive property. On account of this, Okamoto et al. employed a hollow fiber module constituted of an aromatic polyimide membrane in the PV mode which presented problems of plastification. Specifically, the authors reported the PV-coupled esterification of oleic acid at $75{ }^{\circ} \mathrm{C}$ and $98{ }^{\circ} \mathrm{C}$ under atmospheric and elevated pressures respectively [113], by using an internal PV unit with asymmetric hydrophilic poly-etherimide (PEI) and 4-4'-oxydiphenylene pyromellitimide (POPMI) membranes and $p$-toluenesulfonic acid as catalysts. Almost complete conversion was attained using an $\mathrm{m}_{0}$ between ethanol and oleic acid of two in a short time and a low concentration of the catalyst at $98^{\circ} \mathrm{C}$. An increase in temperature of $25^{\circ} \mathrm{C}$ resulted in plasticization of the membrane because of the oleic acid and ethyl oleate present in the feed mixture. Moreover under specific conditions, the loss of ethanol due to 
permeation does not become negligible either at long reaction time or with low selectivity of the membrane: the loss of ethanol due to permeation increases by about $50 \%$ with an increase in $\mathrm{m}_{0}$ from 2 to 3. Authors concluded that it is crucial to develop both a large-scale reactor with high membrane surface/liquid mixture volume $\left(\mathrm{S} / \mathrm{V}_{0}\right)$ ratio and a membrane with a high water permeability constant $\left(\mathrm{P}_{W}\right)$ together with excellent long-term durability.

The $\mathrm{S} / \mathrm{V}_{0}$ ratio represents another key factor affecting the water-separating capacity of a membrane reactor. However, for a VP-assisted reaction, a large-scale reactor with the same $S / V_{0}$ ratio of the laboratory size could be realized considering that the membrane module can be developed independently of the reaction vessel. At the same time, it is more difficult to scale-up the reactor in the case of a PV-coupled reaction.

Sarkar et al. [114] investigated the benefits obtainable by PV driven by temperature gradients, for acid esterification of oleic acid with methanol, which avoided the need of employing an inert sweep gas or vacuum on the downstream side. The membrane used was a PVA cast on PES and, to prevent its damage by acids, the sulfuric acid concentration was reduced to $0.3 \mathrm{wt} \%$. Despite this low catalyst concentration, a $99.9 \%$ conversion at $65^{\circ} \mathrm{C}$ was achieved by exploiting the PV-aided process and, at the same time, the product obtained showed an acid value lower than that indicated by the biodiesel specification. This result could be considered important since the separation of water from methanol is a bigger challenge compared to the dehydration of higher alcohols, due to the polar nature of both molecules. Authors demonstrated the scale-up feasibility of the PVA-PES composite flat sheet into plate and frame modules. A PVA-based membrane (PERVAP 1000, by Sulzer ${ }^{\circledR}$ ) was also used for water removal in biodiesel production by PV-assisted esterification of oleic acid and ethanol, with Amberlyst-15 catalyst, by Figueiredo et al. [115]. The hydrophilic membrane is based on a crosslinked PVA layer coated onto a PAN substrate. The potential of coupling esterification and pervaporation was demonstrated with a 2-fold increase in the oleic acid conversion (above the equilibrium limit) and a high ethyl oleate yield.

By working in VP mode, the same membrane used by Okamoto et al. [113] was stable. Specifically, the esterification reaction of oleic acid in the presence of ethanol coupled with the VP process was studied using a laboratory module of asymmetric polyimide hollow fiber membrane [116]. The reaction performed at the boiling temperature of the reaction mixtures under atmospheric pressure allowed almost complete conversion to be obtained in a short reaction time with a decrease in the initial $\mathrm{m}_{0}$. By using a low ethanol/acid molar ratio, the vapor phase of water component was enriched, thus a more rapid elimination of water was favored. In fact, the composition of vapor phase depends on the composition of volatile components, namely ethanol and water, in the liquid phase. Considering that the membrane was in contact with the volatile components, water and ethanol (and not oleic acid or ethyl oleate), it worked stably for a long period.

Rewagad and Kiss [117] by an appropriate sensitivity analysis study demonstrated that PV technology could enhance the conversion of the fatty ester synthesis by $12.5 \%, 13.2 \%$, and $16.1 \%$ for homogenous, heterogeneous or combined catalytic systems respectively. However, as is well known, liquid mineral acids suffer from many drawbacks, such as their corrosive nature, the possibility of side reactions, and the difficulty in separating the catalyst from the reaction solution. Therefore, heterogeneous processes are preferred from a practical point of view.

On the whole, for the synthesis of biodiesel, the PV or VP coupled system can be used both as a pre-treatment stage or even as an alternative to the transesterification reaction when the free-fatty acids and water contents of the feedstock are high.

\subsection{Biolubricants Production}

Natural lubricants based on ester compounds show many advantages with respect to synthetic ones being non-toxic, biologically degradable, environmentally safe, and low-priced products that can be easily recycled. They are produced by the esterification reaction between long-chain acids and alcohols, both of natural origin (Equation (6)). Fatty acids can be obtained by hydrolysis of plant 
oils, specifically oleic acid is one of the most important fatty acids in nature, whereas the alcohol compounds could be derived from "fusel oil", a by-product in ethanol distilleries, composed of $10 \%$ ethanol, 13\% n-propanol, 15\% $i$-butanol, 51\% $i$-amyl alcohol, 11\% miscellaneous alcohols and water (generally burned to complete energy demand of the distilleries):

$$
\text { Oleic acid }+ \text { fraction of fusel oil } \leftrightarrows \text { oleate esters }+\mathrm{H}_{2} \mathrm{O}
$$

Enzyme catalysis was employed in non-conventional solvent free media in an integrated system, where PV was connected to the bioreactor. Compared to the product obtained by acid catalysis, in the biolubricant there was no trace of oleic acid since complete conversion was achieved by continuous water removal by PV [85]. Dörmő et al. observed that esterification of oleic acid with fusel oil in the presence of enzyme catalyst was $92 \%$ only after $12 \mathrm{~h}$, but an almost total conversion was achieved by the PV-aided process [118].

$i$-Amyl oleate could also be employed as a bio-lubricant and can be obtained by esterification of oleic acid and $i$-amyl alcohol. Koszorz et al. [119] studied such reaction by using an immobilized lipase enzyme, Novozym-435, as a catalyst and a PV system integrated on-line with the reactor. Also in this case, the membrane applied should guarantee the suitable water content needed for enzyme activation. Chamberlain et al. also suggested placing a PV module (with hydrophilic PERVAP-1510 membranes) in front of a multicomponent distillation to dehydrate fusels oils and recover isoamyl alcohol by distillation. The reduction of the water amount in the feed from $14 \%$ to $7 \%$, in fact, allowed the recovery of more than $99 \mathrm{wt} \%$ of isoamyl alcohol [120].

\subsection{Fuel Additives}

Additives are substances added to fuels to enhance their chemico-physical or combustion properties. Oxygenates, for example, are able to increase the anti-detonating power of the gasoline and to guarantee the proper oxygen content established by regulations to limit pollutant emissions. In fact, they could assist in combustion quality by reducing particulate emissions and carbon monoxide production and furthermore in improving the cold and viscosity properties [121]. Tertiary alkyl ethers, such as methyl tert-butyl ether (MTBE), ethyl tert-butyl ether (ETBE) and tert-amylmethyl ether (TAME) have been commonly used as octane improvers for liquid fuels, their low vapor pressure contributing to reduce the vapor pressure of gasoline. Other important bio-based diesel additives are acetals too. Here, some examples of PV- and VP-aided processes for additives production are reported (see Table 3).

The performance of film-like zeolite NaA membranes was evaluated in the synthesis of di- $n$-pentyl ether, a linear symmetric ether which is a good blending additive for diesel fuels, by etherification of $n$-pentanol catalyzed by ion-exchange sulfonated resins [29].

$$
\begin{array}{ccc}
\mathrm{CH}_{3}\left(\mathrm{CH}_{2}\right)_{3} \mathrm{CH}_{2} \mathrm{OH} & \mathrm{CH}_{3}\left(\mathrm{CH}_{2}\right)_{3} \mathrm{CH}_{2} \mathrm{OH} \leftrightarrows \mathrm{CH}_{3}\left(\mathrm{CH}_{2}\right)_{3} \mathrm{CH}_{2} \mathrm{OCH}_{2}\left(\mathrm{CH}_{2}\right)_{3} \mathrm{CH}_{3}+\mathrm{H}_{2} \mathrm{O} \\
\text { n-pentanol } & \text { di-n-pentyl ether } & \text { water }
\end{array}
$$

The catalyst deactivating effect of the water was overcome by employing a separation unit, with a consequent increase in the $n$-pentanol conversion ( $64 \%$ vs. $35 \%$ in the fixed bed reactor).

Salomón et al. [122] applied MR for water removal in the MTBE production with the reaction between methanol and tert-butyl alcohol (TBA) exploiting a zeolite tubular membrane with an internal bed of A-15 catalyst.

$$
\begin{aligned}
& \mathrm{CH}_{3} \mathrm{OH}+\left(\mathrm{CH}_{3}\right)_{3} \mathrm{COH} \leftrightarrows\left(\mathrm{CH}_{3}\right)_{3} \mathrm{CCH}_{3}+\mathrm{H}_{2} \mathrm{O} \\
& \text { Methanol TBA MTBE Water }
\end{aligned}
$$

At $61{ }^{\circ} \mathrm{C}$, MTBE yield reached $67.7 \%$ under conditions where the equilibrium value without product removal would be $60.9 \%$. Some membranes based on NaA and MOR/ZSM5/CHA zeolites were used obtaining water fluxes variable between 0.06 and $0.76 \mathrm{~kg} / \mathrm{m}^{2} / \mathrm{h}$. The permselectivity of 
water was a function of component polarity: $\mathrm{S}_{\mathrm{H} 2 \mathrm{O} / \mathrm{IB}}>\mathrm{S}_{\mathrm{H} 2 \mathrm{O} / \mathrm{MTBE}}>\mathrm{S}_{\mathrm{H} 2 \mathrm{O} / \mathrm{TBA}}>\mathrm{S}_{\mathrm{H} 2 \mathrm{O} / \mathrm{MeOH}}$, (where $\mathrm{IB}$ is isobutylene formed by TBA dehydration). The reaction between TBA and ethanol (EtOH) to synthesize ETBE was investigated by Assaburungrat et al. [123], by employing an immobilized $\beta$-zeolite as catalyst in a pervaporation membrane reactor, comparing its performance under two different continuous modes (i.e., in CSTR and PFR). PFR was preferred to CSTR configuration although, under specific operating conditions (at lower yield), the CSTR setup allowed achievement of a higher yield. At low temperature, a high ETBE yield was obtained by using a high ratio between the membrane area and the catalyst weight, at a stoichiometric value between EtOH and TBA.

However, despite the advantages described by using PV or VP technologies, the membrane processes sometimes suffer from drawbacks if used alone. PV, for example, is unable to achieve products of high purity, because it works with a very low driving force for mass transfer, resulting in low permeate fluxes. To overcome these constraints, membrane integrated hybrid processes have been often exploited to optimize the efficiency of separation processes. Coupling two unit operations with different separation principles, in fact, may bring a synergic effect, and the separation is more effective than the separation obtained with a single unit operation [124], with considerable savings in energy consumption. Lipnizki et al. [50] reviewed the prospects of PV integrated hybrid processes analyzing several studies regarding MTBE and ETBE production. Then, Norkobilov et al. [125] incorporated PV modules in the process flowsheet for the production of ETBE, by applying the hybrid distillation-PV with PERVAP 2256 commercial membranes, to separate the azeotrope ethanol/ETBE. This allowed the exclusion of the main separation unit, so reducing the energy consumption and operating costs and increasing throughput.

As regards acetals, they can be obtained when an alcohol and an aldehyde react together, as shown in Equation (9).

$$
\begin{aligned}
& \mathrm{R}_{1} \mathrm{COH}+\mathrm{R}_{2} \mathrm{OH} \leftrightarrows \mathrm{R}_{1} \mathrm{CHOR}_{2}+\mathrm{H}_{2} \mathrm{O} \\
& \text { Aldehyde Alcohol Acetal Water }
\end{aligned}
$$

An interesting example of industrial application is represented by the 1,1-dimethoxybutane production by bioethanol and butanal by exploiting the HybSi membrane (commercial hybrid silica material). At $70{ }^{\circ} \mathrm{C}$, in fact, the conversion increased from $40 \%$ to $70 \%$ thanks to the coupling in a single unit of the reaction with the membrane reactor [126].

The potential of the patented PermSMBR technology was probed in the production of the biofuel 1,1-diethoxyethane by acetalization of acetaldehyde with ethanol, in presence of Amberlyst 15-wet as both catalyst and adsorbent. Compared to standard SMBR technology, PermSMBR led to a decrease in ethanol consumption of $69 \%$ and a significant enhancement of diethylacetal productivity $[13,20]$. The same technology was also tested for the production of 1,1-dibutoxyethane (DBE) from acetaldehyde and $n$-butanol, the best performance being achieved at $70{ }^{\circ} \mathrm{C}$ with a maximum productivity of $70.77 \mathrm{~kg}_{\mathrm{DBE}} / \mathrm{L}_{\mathrm{cat}} /$ day and a minimum desorbent consumption of $0.33 \mathrm{~L}_{\mathrm{ButOH}} / \mathrm{kg}_{\mathrm{DBE}}$, representing a productivity improvement of $31 \%$ and a reduced consumption of desorbing compound close to $85 \%$ if compared with SMBR technology [14,20]. Moreover, for the production of DBE the authors also proposed a modified PermSMBR configuration (coupled PermSMBR), where each SMBR column was followed by a membrane module. In such a configuration, the membranes are not in contact with the catalyst/adsorbent in order to preserve their mechanical and chemical resistance and this provides an easier implementation from an industrial point of view. Quantitatively, "coupled PermSMBR" and "integrated PermSMBR" showed similar values of DBE productivity, although in the coupled configuration the solvent consumption was higher [15].

Further the potential of membrane technology within the production of fuel additives was assessed in the enhancement of 1,1-diethoxybutane synthesis by acetalization of ethanol with butyraldehyde under acidic conditions, in which a microporous silica membrane (Pervatech BV) was an effective pervaporation medium with high selectivity for water, outlining a great perspective for application in the PermSMBR configuration [16]. In principle, the permeation properties of the 
PERVATECH BV membrane could be useful in various applications implying the recovery of building block organics from aqueous mixtures [18].

In the last decades, due to the increasing demand for production of biodiesel, significant growth in glycerol amounts has occurred, it being the major by-product $(\approx 10 \mathrm{wt} \%)$ of the transesterification reaction of vegetable oils (Equation (2)) [104]. So glycerol was considered as a valuable source to produce fuel additives. In fact, among the different approaches proposed recently to convert it to the added-value products, the possibility of producing oxygenated additives by either etherification or esterification reaction has received great attention. The fuel additives produced from glycerol have physico-chemical properties (i.e., flash point, viscosity, cetane number etc.) compatible with a diesel vehicle engine.

Mono-acylglycerol (MAG), di-acylglycerol (DAG) and tri-acylglycerol (TAG) are produced by glycerol esterification with acetic acid (Equations (10)-(12)) but only higher-substituted ethers (di- and tri-ethers) could be considered appropriate as diesel additives thanks to their suitable properties in terms of blending with diesel fuels and their cetane number [103].

The reaction is characterized by a three step mechanism which leads to the production of mono-, di- and tri-substituted ethers with formation of a mole of water for each mole of ester (Equations (10)-(12)) so water removal is essential to overcome the equilibrium constraints and to shift the reaction towards poly-ether compounds obtaining higher conversion and selectivities.

$$
\begin{aligned}
\text { Glycerol }+ \text { acetic acid } & \leftrightarrows \mathrm{MAG}+\mathrm{H}_{2} \mathrm{O} \\
\mathrm{MAG}+\text { acetic acid } & \leftrightarrows \mathrm{DAG}+\mathrm{H}_{2} \mathrm{O} \\
\mathrm{DAG}+\text { acetic acid } & \leftrightarrows \mathrm{TAG}+\mathrm{H}_{2} \mathrm{O}
\end{aligned}
$$

Among different approaches exploited, for example, a $\mathrm{Zr}\left(\mathrm{SO}_{4}\right)_{3} \cdot 4 \mathrm{H}_{2} \mathrm{O}$ loaded chitosan catalytic membrane was suggested [103]. The reactions of esterification were carried out in a batch reactor and in PV catalytic membrane reactor, TRPV (CMR), thus obtaining higher conversions values. The reaction takes place in the catalytic area of the membrane and the conversion increased because of the selective removal of product from the separation area of the membrane (see Figure 3). The catalyst in the membrane was used repeatedly without the need for additional separation or cleaning steps.

Up to today, the first and a unique application of water removal by using a VP membrane reactor in glycerol etherification reaction was proposed by Cannilla et al. [127] by coupling a stirred tank

\begin{tabular}{|c|c|}
\hline & Legend \\
\hline$\varpi$ & Tip \\
\hline$\nabla$ & Batch reactor \\
\hline (1) & Pressure controller \\
\hline 承 & Needle valve \\
\hline$H_{\Delta}$ & Safety valve \\
\hline $\mathbb{S}$ & Three-way valve \\
\hline$\infty$ & $\begin{array}{l}\text { Single stage } \\
\text { pressure regulator }\end{array}$ \\
\hline PT & $\begin{array}{l}\text { Pressure } \\
\text { transducer }\end{array}$ \\
\hline (d) $\mathrm{TC}$ & Thermoregulator \\
\hline$\Leftrightarrow$ & Membrane \\
\hline - 파- & Condenser \\
\hline 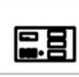 & $\begin{array}{l}\text { Temperature } \\
\text { controller, stirrer } \\
\text { and pressure gauge }\end{array}$ \\
\hline
\end{tabular}
reactor with a permselective membrane. The membrane-reactor configuration used is shown in Figure 4 for the etherification of glycerol (Gly) with TBA (Equations (13)-(15)).

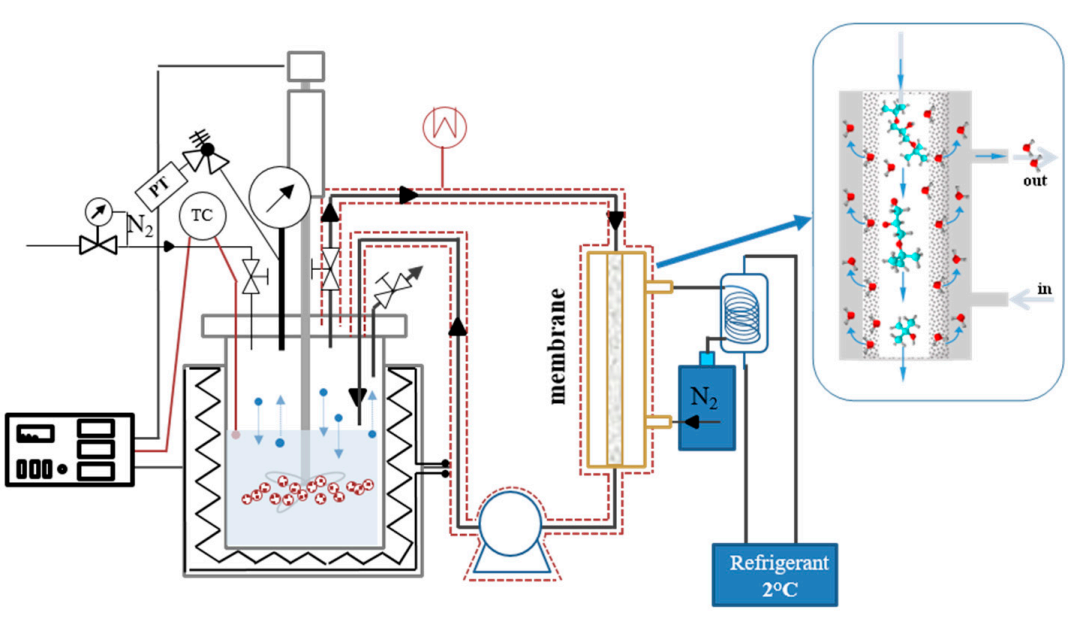

Figure 4. VP-coupled batch reactor for glycerol etherification with TBA. 
The reaction catalyzed by acid homogeneous or better solid systems follows three consecutive steps which lead to a mixture of glycerol tert-butylethers: two mono-tert-butylglycerol ethers (MTGEs), two di-tert-butylglycerol ethers (DTGEs) and tri-tert-butylglycerol ether (TTGE).

$$
\begin{gathered}
\text { Gly }+ \text { TBA } \leftrightarrows \text { MTGEs }+\mathrm{H}_{2} \mathrm{O} \\
\text { MTGEs }+ \text { TBA } \leftrightarrows \text { DTGEs }+\mathrm{H}_{2} \mathrm{O} \\
\text { DTGEs }+ \text { TBA } \leftrightarrows \text { TTGE }+\mathrm{H}_{2} \mathrm{O}
\end{gathered}
$$

Also in this case, only higher substituted ethers are suitable additives being soluble in diesel fuels; while the mono-ethers must be eliminated from the ether mixture to avoid deposit formation during the blending procedure [91]. This makes it necessary to drive the reaction towards higher-ether production. Until today, as concerns the glycerol etherification reaction with TBA, only a few studies have proposed the exploitation of separation processes for water removal from the reaction medium, as for example, the application of a reactor coupled with a distillation system [128]. The glycerol etherification reaction was investigated in a PFR, in the presence of Ambelyst 15 as catalyst; two distillation columns were employed for the separation step and the attainment of high purity ethers. An extractive distillation unit with 1,4-butanediol was also required to separate TBA from the alcohol/water azeotrope formed [129] along with the MTGEs recycle. Another preliminary approach was investigated by using zeolites to remove the water, but they required a regeneration step to be reused [130]. Also Ozbay et al. studied water separation by sorption with a zeolite physically mixed with the catalyst and packed into a flow reactor which allowed an important increase in glycerol conversion and DTGEs selectivity to be achieved [131].

So, to overcome the equilibrium limits and to shift the reaction towards higher-ethers, by using the VP-aided system depicted in Figure 4, the gas phase (mainly containing TBA and $\mathrm{H}_{2} \mathrm{O}$ ) was recirculated through the membrane. This is a commercial water permselective membrane, HybSi, provided by Pervatech BV, constituted of a $\gamma$-alumina tubular phase coated with organic polymer.

At the permeate side of the membrane, the flux was maintained under vacuum by continuous pumping to avoid the condensation of water or it was purged with a nitrogen stream. The reaction was carried out under mild reaction $\left(70-80^{\circ} \mathrm{C}\right)$ conditions by using solid acid catalysts. Specifically, by setting the appropriate reaction parameters and employing a proper solid catalyst based on hyflon $/ \mathrm{SiO}_{2}$, significant benefits were obtained by using the membrane both in terms of glycerol conversion, which was almost total, and poly-ether selectivity: in one single step, a clean ether mixture was obtained, without glycerol, containing about $80 \mathrm{wt} \%$ of di- and tri-ethers, which could be directly used as additive, without the need of additional separation steps [127,132].

The etherification of glycerol with butanol (BUT) as renewable $O$-alkylating reagent (Equations (16)-(18)) [133] was investigated too by exploiting the same membrane reactor device. The use of bio-butanol or bio-ethanol in fact is an important alternative way to valorize the glycerol, which is formed during biodiesel production, thus obtaining a completely sustainable process.

$$
\begin{gathered}
\mathrm{Gly}+\mathrm{BUT} \leftrightarrows \mathrm{MBGEs}+\mathrm{H}_{2} \mathrm{O} \\
\text { MBGEs }+\mathrm{TBA} \leftrightarrows \mathrm{DBGEs}+\mathrm{H}_{2} \mathrm{O} \\
\text { DBGEs }+\mathrm{TBA} \leftrightarrows \mathrm{TBGE}+\mathrm{H}_{2} \mathrm{O}
\end{gathered}
$$

Also in this case, di-and tri-poly butyl substituted ethers (DBGEs, TBGE) could be used as suitable additives in diesel mixture thanks to their high solubility in this fuel. The amphiphilic mono-butyl glycerol ethers (MBGEs), instead, could represent a green solvent for catalysis [134] or the precursor for surfactants production [135]. With butanol as reactant, the equilibrium was shifted towards the formation of several products. Unfortunately, up today, it was not possible to produce only di- and tri-ether substituted compounds, since in the presence of acid catalyst, at $140{ }^{\circ} \mathrm{C}$, the selective removal 
of water also improves the dehydrogenation and self-etherification of glycerol or alkyl alcohols. On account of this, the reaction parameters used produced compounds difficult to separate from the reaction mixture and sometimes hard to identify. Further studies are in progress in order to optimize the reaction conditions and find the suitable conditions to exploit the membrane module performance.

\section{Conclusions}

Recent economic and environmental considerations have encouraged the chemical industry to focus on novel reactive separation technologies based on process intensification. On account of this, membrane separation techniques have the advantages of high efficiency, energy saving, economy, environmental friendliness, flexibility etc. and could be applied for the separation of all kinds of liquid mixtures over all concentration ranges, representing a concrete solution for many processes even on a large scale. Membranes should be characterized by suitable properties, such as mechanical, chemical, and thermal stress resistance, high surface area per unit volume available, high selectivity, but at the same time by the capacity to govern the contact of components between two phases. These properties make them good candidates for liquid biofuel production as biodiesel and additives. Specifically, in recent years, PV and VP have been considered as green technology for the dehydration of organic solvents, such as alcohols, ethers, esters, and ketones, as well as for the removal of organics from aqueous streams or separating different types of mixtures of organic compounds. Many important results have been obtained in liquid biofuel and additive production, reaching high reactant conversion and high yields, with consequent advantages in terms of product quality while limiting production cost and environmental questions. The coupling of the reaction and separation, in fact, allows the equilibrium limitations to be overcome providing important benefits over conventional processes, above all if solid catalysts are employed and the integration of heat is exploited. However, many of the PV and VP applications are under study (laboratory scale) and thus they require optimization of process parameters, from the catalytic side (reaction temperature, reactant ratio, catalyst concentration) as well as the membrane side (reactant flow rate, pressure, membrane thickness, pore size etc.). Moreover, the preferred reactor configuration for using a membrane in a catalytic reaction is a function of many factors that should be carefully evaluated. For example, in order to avoid the damage of a membrane by an acidic environment, novel strategies have been investigated by employing two separate chemical and membrane units, by exploiting the VP configuration instead of PV or also by designing innovative higher acid-resistant membranes (as zeolites), suitable heterogeneous catalysts (as an acid resin) or catalytically active membranes.

As regards zeolite membranes, important developments have been undertaken allowing suitable permeation characteristics, but also easier and cheaper upscaling, thus supported zeolite membranes could be considered good candidates for industrial applications in the future.

Anyhow, even if the progress in membrane-based integrated processes continues to grow, to allow real industrialization of the PV and VP processes, new practical and theoretical efforts should be still carried out both to design novel cheaper membranes, characterized by high flux, selectivity and stability, and also for a better understanding of the complex phenomena of PV and VP, thus shedding light on the real potential of such techniques. A critical point for example is represented by the fouling effect and, in general, the stability of the membranes. At the same time, the optimization of low-cost active solid catalysts is a key factor in attaining high yields of biofuels and additives.

Acknowledgments: Part of this work was realized within the bilateral agreement of Scientific and Technological Cooperation CNR-HAS (Hungarian Academy of Sciences).

Author Contributions: All authors contributed equally to this work, in terms of bibliographic collection, analysis of data, creation of Tables and Figures, writing of the text.

Conflicts of Interest: The authors declare no conflict of interest. 


\section{Nomenclature}

\begin{tabular}{|c|c|}
\hline BUT & Butanol \\
\hline CHA & Chabazite \\
\hline CMR & Catalytic Membrane Reactor \\
\hline CSTR & Continuous Stirred Tank Reactor \\
\hline $\mathrm{CST}+\mathrm{PV}$ & Continuous Stirred Tank reactor with external Pervaporation unit \\
\hline $\mathrm{CST}+\mathrm{VP}$ & Continuous Stirred Tank reactor with external Vapor Permeation unit \\
\hline CSTPV & Continuous Stirred Tank reactor with internal Pervaporation unit \\
\hline CSTVP & Continuous Stirred Tank reactor with internal Vapor Permeation unit \\
\hline DAG & di-acylglycerol \\
\hline DBE & 1,1-dibutoxyethane \\
\hline DBGEs & di-butylglycerol ethers \\
\hline DTGEs & di-tert-butylglycerol ethers \\
\hline ETBE & Ethyl tert-butyl ether \\
\hline FAAEs & Fatty Acid Alkyl Esters \\
\hline FAMEs & Fatty Acid Methyl Esters \\
\hline FFAs & Free Fatty Acids \\
\hline GLY & Glycerol \\
\hline $\mathrm{m}_{0}$ & Initial Molar Ratio \\
\hline MAG & mono-acylglycerol \\
\hline MBGEs & mono-butylglycerol ethers \\
\hline MER & Merlionite \\
\hline MMM & Mixed Matrix Membrane \\
\hline MR & Membrane Reactor \\
\hline MTBE & Methyl tert-butyl ether \\
\hline MTGEs & mono-tert-butylglycerol ethers \\
\hline $\mathrm{P}$ & Permeability constant $[\mathrm{m} / \mathrm{h}]$ \\
\hline $\mathrm{P}_{\mathrm{W}}$ & Water Permeability constant \\
\hline PAN & Polyacrylonitrile \\
\hline PDMS & Polydimethylsiloxane \\
\hline PEI & Poly-etherimide \\
\hline PermSMBR & coupling of permselective membrane with SMBR \\
\hline PES & Polyethersulfone \\
\hline PFR & lug Flow Reactor \\
\hline $\mathrm{PFR}+\mathrm{PV}$ & Plug Flow Reactor with external Pervaporation unit \\
\hline $\mathrm{PFR}+\mathrm{VP}$ & Plug Flow Reactor with external Vapor Permeation unit \\
\hline PFRPV & Plug Flow Reactor with internal Pervaporation unit \\
\hline PHI & Phillipsite \\
\hline POPMI & poly $\left(4,4^{\prime}\right)$-oxydiphenylene pyromellitimide \\
\hline PV & Pervaporation \\
\hline PVA & Polyvinyl Alcohol \\
\hline PVMR & Pervaporation Membrane Reactor \\
\hline S & Effective membrane area $\left[\mathrm{m}^{2}\right]$ \\
\hline SBPV & Semi Batch Reactor with internal PV unit \\
\hline $\mathrm{SB}+\mathrm{PV}$ & Semi Batch Reactor with external PV unit \\
\hline SMBR & Simulated Moving Bed Reactor \\
\hline SOD & Sodalite \\
\hline TAG & tri-acylglycerol \\
\hline TAME & tert-amyl methyl ether \\
\hline TBA & tert-butyl alcohol \\
\hline TBGE & tri-butylglycerolether \\
\hline
\end{tabular}




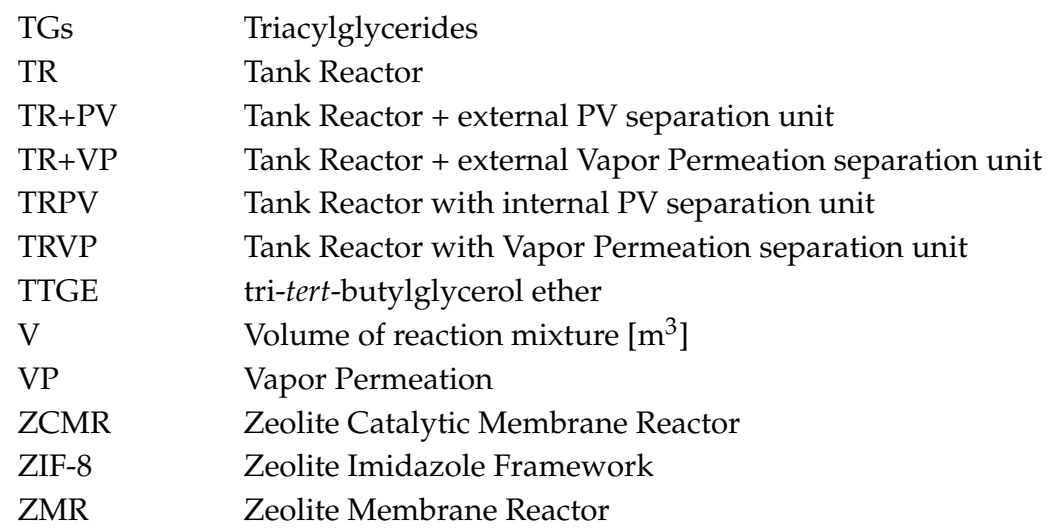

\section{References}

1. Jyoti, G.; Keshav, A.; Anandkumar, J. Review on Pervaporation: Theory, Membrane Performance, and Application to Intensification of Esterification Reaction. J. Eng. 2015. [CrossRef]

2. Feng, X.; Huang, R.Y.M. Liquid Separation by Membrane Pervaporation: A Review. Ind. Eng. Chem. Res. 1997, 36, 1048-1066. [CrossRef]

3. Kiss, A.A. Process Intensification Technologies for Biodiesel Production. Reactive Separation Processes; Springer: Cham, Switzerland, 2014.

4. Kiss, A.A.; Bildea, C.S. A review of biodiesel production by integrated reactive separation technologies. J. Chem. Technol. Biotechnol. 2012, 87, 861-879. [CrossRef]

5. Gubicza, L.; Kabiri-Badr, A.; Keoves, E.; Belafi-Bako, K. Large-scale enzymatic production of natural flavour esters in organic solvent with continuous water removal. J. Biotechnol. 2000, 84, 193-196. [CrossRef]

6. Jeong, J.C.; Lee, S.B. Enzymatic esterification reaction in organic media with continuous water stripping: Effect of water content on reactor performance and enzyme agglomeration. Biotechnol. Tech. 1997, 11, 853-858. [CrossRef]

7. Kvittingen, L.; Sjursnes, B.; Anthonsen, T.; Halling, P. Use of salt hydrates to buffer optimal water level during lipase catalysed in synthesis in organic media: A practical procedure for organic chemists. Tetrahedron 1992, 48, 2793-2802. [CrossRef]

8. Wehtje, E.; Kaur, J.; Adlercreutz, P.; Chand, S.; Mattiasson, B. Water activity control in enzymatic esterification processes. Enzyme Microb. Technol. 1997, 21, 502-510. [CrossRef]

9. Kujawski, W. Application of Pervaporation and Vapor Permeation in Environmental Protection. Pol. J. Environ. Stud. 2000, 9, 13-26.

10. Trusek-Holownia, A.; Noworyta, A. An integrated process: Ester synthesis in an enzymatic membrane reactor and water sorption. J. Biotechnol. 2007, 130, 47-56. [CrossRef] [PubMed]

11. Tanaka, K.; Yoshikawa, R.; Ying, C.; Kita, H.; Okamoto, K.I. Application of zeolite T membrane to vapor-permeation-aided esterification of lactic acid with ethanol. Chem. Eng. Sci. 2002, 57, 1577-1584. [CrossRef]

12. Espro, C.; Bonura, G.; Arena, F.; Frusteri, F; Parmaliana, A.; Sini, F.; Solinas, V. Factors affecting the efficiency of Nafion-based catalytic membranes in the selective oxidation of light paraffins mediated by the Fenton system. Catal. Today 2004, 91-92, 215-218. [CrossRef]

13. Silva, V.M.T.M.; Pereira, C.S.M.; Rodrigues, A.E. PermSMBR-A New Hybrid Technology: Application on Green Solvent and Biofuel production. AIChE J. 2011, 57, 1841-1851. [CrossRef]

14. Pereira, C.S.M.; Silva, V.M.T.M.; Rodrigues, A.E. Green Fuel Production Using the PermSMBR Technology. Ind. Eng. Chem. Res. 2012, 51, 8928-8938. [CrossRef]

15. Pereira, C.S.M.; Silva, V.M.T.M.; Rodrigues, A.E. Coupled PermSMBR—Process design and development for 1,1-dibutoxyethane production. Chem. Eng. Res. Des. 2014, 92, 2017-2026. [CrossRef]

16. Graça, N.S.; Rodrigues, A.E. Application of membrane technology for the enhancement of 1,1-Diethoxybutane synthesis. Chem. Eng. Process. Process Intensif. 2017, 117, 45-57. [CrossRef]

17. Faria, R.P.V.; Pereira, C.S.M.; Silva, V.M.T.M.; Loureiro, J.M.; Rodrigues, A.E. Sorption Enhanced Reactive Process for the Synthesis of Glycerol Ethyl Acetal. Chem. Eng. J. 2014, 258, 229-239. [CrossRef] 
18. Boutikos, P.; Pereira, C.S.M.; Silva, V.M.T.M.; Rodrigues, A.E. Performance Evaluation of Silica Membrane for Water-n-butanol Binary Mixture. Sep. Purif. Technol. 2014, 127, 18-28. [CrossRef]

19. Faria, R.P.V.; Pereira, C.S.M.; Silva, V.M.T.M.; Loureiro, J.M.; Rodrigues, A.E. Glycerol valorisation as biofuels: Selection of a suitable solvent for an innovative process for the synthesis of GEA. Chem. Eng. J. 2013, 233, 159-167. [CrossRef]

20. Pereira, C.S.M.; Rodrigues, A.E. Process Intensification: New technologies (SMBR and PermSMBR) for the synthesis of Acetals. Catal. Today 2013, 218-219, 148-152. [CrossRef]

21. Drioli, E.; Fontananova, E. Membrane Materials for Addressing Energy and Environmental Challenges. Annu. Rev. Chem. Biomol. Eng. 2012, 3, 395-420. [CrossRef] [PubMed]

22. Unlu, D.; Hilmioglu, N.D. Pervaporation catalytic membrane reactor study for the production of ethyl acetate using $\mathrm{Zr}\left(\mathrm{SO}_{4}\right)_{2}{ }^{*} 4 \mathrm{H}_{2} \mathrm{O}$ coated chitosan membrane. J. Chem. Technol. Biotechnol. 2016, 91, 122-130. [CrossRef]

23. Lee, Y.-C.; Dutta, S.; Wu, K.C.-W. Integrated, Cascading Enzyme-/Chemocatalytic Cellulose Conversion using Catalysts based on Mesoporous Silica Nanoparticles. ChemSusChem 2014, 7, 3241-3246. [CrossRef] [PubMed]

24. Lee, Y.-C.; Chen, C.-T.; Chiu, Y.-T.; Wu, K.C.-W. An Effective Cellulose-to-Glucose-to-Fructose Conversion Sequence by Using Enzyme Immobilized $\mathrm{Fe}_{3} \mathrm{O}_{4}$-Loaded Mesoporous Silica Nanoparticles as Recyclable Biocatalysts. ChemCatChem 2013, 5, 2153-2157. [CrossRef]

25. Alam, I.M.; De, S.; Singh, B.; Saha, B. Titanium hydrogenphosphate: An efficient dual acidic catalyst for 5-hydroxymethylfurfural (HMF) production. Appl. Catal. A 2014, 486, 42-48. [CrossRef]

26. Jeong, G.-T.; Ra, C.H.; Hong, Y.-K.; Kim, J.K.; Kong, I.-S.; Kim, S.-K.; Park, D.-H. Conversion of red-algae Gracilaria verrucosa to sugars, levulinic acid and 5-hydroxymethylfurfural. Bioprocess Biosyst. Eng. 2015, 38, 207-217. [CrossRef] [PubMed]

27. Kuo, I.-J.; Suzuki, N.; Yamauchi, Y.; Wu, K.C.-W. Cellulose-to-HMF conversion using crystalline mesoporous titania and zirconia nanocatalysts in ionic liquid systems. RSC Adv. 2013, 3, 2028-2034. [CrossRef]

28. Hsu, W.-H.; Lee, Y.-Y.; Peng, W.-H.; Wu, K.C.-W. Cellulosic conversion in ionic liquids (ILs): Effects of $\mathrm{H}_{2} \mathrm{O}$ /cellulose molar ratios, temperatures, times, and different ILs on the production of monosaccharides and 5-hydroxymethylfurfural (HMF). Catal. Today 2011, 174, 65-69. [CrossRef]

29. Pera-Titus, M.; Llorens, J.; Cunill, F. Technical and economical feasibility of zeolite NaA membrane-based reactors in liquid-phase etherification reactions. Chem. Eng. Process. Process Intensif. 2009, 48, 1072-1079. [CrossRef]

30. Basile, A.; Figoli, A.; Khayet, M. Pervaporation, Vapour Permeation and Membrane Distillation: Principles and Applications; Woodhead Publishing in Elsevier: Kidlington, UK, 2015.

31. Marszałek, J.; Kamiński, W. Environmental impact of bioethanol production. Proc. ECOpole 2008, 2, 65-70.

32. Sander, U.; Soukup, P.B. Design and operation of pervaporation plant for ethanol dehydration. J. Membr. Sci. 1988, 36, 463-475. [CrossRef]

33. Sander, U.; Soukup, P.B. Practical experience with pervaporation systems for liquid and vapour separation. J. Membr. Sci. 1991, 62, 67-89.

34. Ohlemann, B. Chemicals: Pervaporation and vapour permeation processes meet specialist needs. Filtr. Sep. 2012, 49, 18-22. [CrossRef]

35. Bowen, T.C.; Noble, R.D.; Falconer, J.L. Fundamentals and applications of pervaporation through zeolite membranes. J. Membr. Sci. 2004, 245, 1-33. [CrossRef]

36. Benedict, D.J.; Parulekar, S.J.; Tsai, S.-P. Esterification of Lactic Acid and Ethanol with/without Pervaporation. Ind. Eng. Chem. Res. 2003, 42, 2291. [CrossRef]

37. Brinkmann, T.; Dijkstra, M.; Ebert, K.; Ohlrogge, K. Improved simulation of a vapour permeation module. J. Chem. Technol. Biotechnol. 2003, 78, 332-337. [CrossRef]

38. Bolto, B.; Hoang, M.; Xie, Z. A review of water recovery by vapour permeation through membranes. Water Res. 2012, 46, 259-266. [CrossRef] [PubMed]

39. Teng, M.-Y.; Lee, K.-R.; Fan, S.-C.; Liaw, D.-J.; Huang, J.; Lai, J.-Y. Development of aromatic polyamide membranes for pervaporation and vapor permeation. J. Membr. Sci. 2000, 164, 241-249. [CrossRef]

40. Sander, U.; Janssen, H. Industrial application of vapour permeation. J. Membr. Sci. 1991, 61, 113-129. [CrossRef] 
41. Fan, S.C.; Li, C.L.; Wang, Y.C.; Lee, K.R.; Liaw, D.J.; Lai, J.Y. Application of aromatic polyamide membranes for pervaporation and vapor permeation. Desalination 2002, 148, 43-48. [CrossRef]

42. Armor, J.N. Membrane catalysis: Where is it now, what needs to be done? Catal. Today 1995, 25, $199-207$. [CrossRef]

43. Giorno, L.; Drioli, E. Biocatalytic membrane reactors: Applications and perspectives. Trends Biotechnol. 2000, 18, 339-349. [CrossRef]

44. Pabby, A.K.; Rizvi, S.S.H.; Requena, A.M.S. (Eds.) Handbook of Membrane Separations: Chemical, Pharmaceutical, and Biotechnological Applications, 2nd ed.; CRC Press, Taylor \& Francis Group: Raton, FL, USA, 2015.

45. Shao, P.; Huang, R.Y.M. Polymeric membrane pervaporation. J. Membr. Sci. 2007, 287, 162-179. [CrossRef]

46. Gallucci, F.; Basile, A.; Hai, F.I. Introduction-A Review of Membrane Reactors. In Membranes for Membrane Reactors; John Wiley \& Sons, Ltd.: Chichester, UK, 2011; pp. 1-61.

47. Parulekar, S.J. Analysis of Pervaporation-Aided Esterification of Organic Acids. Ind. Eng. Chem. Res. 2007, 46, 8490-8504. [CrossRef]

48. Drioli, E.; Stankiewicz, A.I.; Macedonio, F. Membrane engineering in process intensification-An overview. J. Membr. Sci. 2011, 380,1-8. [CrossRef]

49. Dragomirova, R.; Wohlrab, S. Zeolite membrane in Catalysis-From separate units to particle coatings. Catalysts 2015, 5, 2161-2222. [CrossRef]

50. Lipnizki, F.; Field, R.W.; Ten, P.-K. Pervaporation-based hybrid process: A review of process design, applications and economics. J. Membr. Sci. 1999, 153, 183-210. [CrossRef]

51. Armor, J.N. Applications of catalytic inorganic membrane reactors to refinery products. J. Membr. Sci. 1998, 147, 217-233. [CrossRef]

52. Takht Ravanchi, M.; Kaghazchi, T.; Kargari, A. Application of membrane separation processes in petrochemical industry: A review. Desalination 2009, 235, 199-244. [CrossRef]

53. Diban, N.; Aguayo, A.T.; Bilbao, J.; Urtiaga, A.; Ortiz, I. Membrane reactors for in situ water removal: A review of applications. Ind. Eng. Chem. Res. 2013, 52, 10342-10354. [CrossRef]

54. Lim, Y.S.; Park, B.; Hung, F.; Sahimi, M.; Tsotsis, T.T. Design issues of pervaporation membrane reactors for esterification. Chem. Eng. Sci. 2002, 57, 4933-4946. [CrossRef]

55. Dams, A.; Krug, J. Pervaporation aided esterification alternatives in plant extension for an existing chemical process. In Proceedings of the Fifth International Conference on Pervaporation Process in the Chemical Industries, Heidelberg, Germany, 11-15 March 1991; Bakish, R., Ed.; Bakish Material Corporation: Englewood, NJ, USA, 1991; pp. 338-348.

56. Peters, T.A. Catalytic Pervaporation Membranes for Close Integration of Reaction and Separation; Eindhoven University of Technology: Eindhoven, The Netherlands, 2006.

57. Nguyen, Q.T.; M’Bareck, C.O.; David, M.O.; Métayer, M.; Alexandre, S. Ion-exchange membranes made of semi-interpenetrating polymer networks, used for pervaporation-assisted esterification and ion transport. Mater. Res. Innov. 2003, 7, 212-219. [CrossRef]

58. Morigami, Y. The first large-scale pervaporation plant using tubular-type module with zeolite NaA membrane. Sep. Purif. Technol. 2001, 25, 251-260. [CrossRef]

59. Kondo, M.; Komori, M.; Kita, H.; Okamoto, K.-I. Tubular-type pervaporation module with zeolite NaA membrane. J. Membr. Sci. 1997, 133, 133-141. [CrossRef]

60. Cui, Y.; Kita, H.; Okamoto, K.-I. Zeolite T membrane: Preparation, characterization, pervaporation of water/organic liquid mixtures and acid stability. J. Membr. Sci. 2004, 236, 17-27. [CrossRef]

61. Li, G.; Kikuchi, E.; Matsukata, M. Separation of water-acetic acid mixtures by pervaporation using a thin mordenite membrane. Sep. Purif. Technol. 2003, 32, 199-206. [CrossRef]

62. Lovallo, M.C.; Tsapatsis, M.; Okubo, T. Preparation of an Asymmetric Zeolite L Film. Chem. Mater. 1996, 8, 1579-1583. [CrossRef]

63. Pina, M.P.; Arruebo, M.; Felipe, M.; Fleta, F.; Bernal, M.P.; Coronas, J.; Menéndez, M.; Santamaría, J. A semi-continuous method for the synthesis of NaA zeolite membranes on tubular supports. J. Membr. Sci. 2004, 244, 141-150. [CrossRef]

64. Deng, Y.-H.; Chen, J.-T.; Chang, C.-H.; Liao, K.-S.; Tung, K.-L.; Price, W.E.; Yamauchi, Y.; Wu, K.C.-W. A Drying-Free, Water-Based Process for Fabricating Mixed-Matrix Membranes with Outstanding Pervaporation Performance. Angew. Chem. Int. Ed. 2016, 55, 12793-12796. [CrossRef] [PubMed] 
65. Yan, Y.; Bornscheuer, U.T.; Schmid, R.D. Efficient water removal in lipase-catalyzed esterifications using a low-boiling-point azeotrope. Biotechnol. Bioeng. 2002, 78, 31-34. [CrossRef] [PubMed]

66. Richardson, J.J.; Björnmalm, M.; Caruso, F. Technology-driven layer-by-layer assembly of nanofilms. Science 2015, 348, aaa2491. [CrossRef] [PubMed]

67. Krupiczka, R.; Koszorz, Z. Activity-based model of the hybrid process of an esterification reaction coupled with pervaporation. Sep. Purif. Technol. 1999, 16, 55-59. [CrossRef]

68. Hasanoğlu, A.; Salt, Y.; Keleşer, S.; Dinçer, S. The esterification of acetic acid with ethanol in a pervaporation membrane reactor. Desalination 2009, 245, 662-669. [CrossRef]

69. Sanz, M.T.; Gmehling, J. Esterification of acetic acid with isopropanol coupled with pervaporation Part I: Kinetics and pervaporation studies. Chem. Eng. J. 2006, 123, 1-8. [CrossRef]

70. Domingues, L.; Recasens, F.; Larrayoz, A. Studies of a pervaporation reactor: Kinetics and equilibrium shift in benzyl alcohol acetylation. Chem. Eng. Sci. 1999, 54, 1461-1465. [CrossRef]

71. Sekulic, J. Mesoporous and Microporous Titania Membranes. Ph.D. Thesis, University of Twente, Enschede, The Netherlands, 2004.

72. Inoue, T.; Nagase, T.; Hasegawa, Y.; Kiyozumi, Y.; Sato, K.; Nishioka, M.; Hamakawa, S.; Mizukami, F. Stoichiometric Ester Condensation Reaction Processes by Pervaporative Water Removal via Acid-Tolerant Zeolite Membranes. Ind. Eng. Chem. Res. 2007, 46, 3743-3750. [CrossRef]

73. De la Iglesia, Ó.; Mallada, R.; Menéndez, M.; Coronas, J. Continuous zeolite membrane reactor for esterification of ethanol and acetic acid. Chem. Eng. J. 2007, 131, 35-39. [CrossRef]

74. Tanaka, K.; Yoshikawa, R.; Ying, C.; Kita, H.; Okamoto, K.I. Application of zeolite membranes to esterification reactions. Catal. Today 2001, 67, 121-125. [CrossRef]

75. Zhang, W.; Na, S.; Li, W.; Xing, W. Kinetic modelling of pervaporation aided esterification of propionic acid and ethanol using T-type zeolite membrane. Ind. Eng. Chem. Res. 2015, 54, 4940-4946. [CrossRef]

76. Zhu, Y.; Minet, R.G.; Tsotsis, T.T. A continuous pervaporation membrane reactor for the study of esterification reactions using a composite polymeric/ceramic membrane. Chem. Eng. Sci. 1996, 51, 4103-4113. [CrossRef]

77. Feng, X.; Huang, R.Y.M. Studies of a membrane reactor: Esterification facilitated by pervaporation. Chem. Eng. Sci. 1996, 51, 4673-4679. [CrossRef]

78. Li, X.; Wang, L. Kinetic model for an esterification process coupled by pervaporation. J. Membr. Sci. 2001, 186, 19-24.

79. Liu, Q.; Zhang, Z.; Chen, H. Study on the coupling of esterification with pervaporation. J. Membr. Sci. 2001, 182, 173-181. [CrossRef]

80. Liu, Q.L.; Chen, H.F. Modeling of esterification of acetic acid with $n$-butanol in the presence of $\mathrm{Zr}\left(\mathrm{SO}_{4}\right)_{2}$ $4 \mathrm{H}_{2} \mathrm{O}$ coupled pervaporation. J. Membr. Sci. 2002, 196, 171-178. [CrossRef]

81. Khajavi, S.; Jansen, J.C.; Kapteijin, F. Application of sodalite membrane reactor in esterification-coupling reaction and separation. Catal. Today 2010, 156, 132-139. [CrossRef]

82. David, M.O.; Gref, R.; Nguyen, T.Q.; Neek, J. Pervaporation esterification coupling. Part I. Basic kinetic model. Trans. IChemE 1991, 69, 335-340.

83. Caro, J. Volume 3.01 Basic aspects of membrane reactors. In Comprehensive Membrane Science and Engineering; Drioli, E., Giorno, L., Eds.; Elsevier: Oxford, UK, 2010; pp. 1-24.

84. Saracco, G.; Specchia, V. Catalytic inorganic membrane reactor: Present experience and future opportunities. Catal. Rev. 1994, 36, 305-384. [CrossRef]

85. Téllez, C.; Menéndez, M. Zeolite membrane reactors. In Membranes for Membrane Reactors; John Wiley \& Sons, Ltd.: Chichester, UK, 2011; pp. 243-273.

86. Gallucci, F.; Fernandez, E.; Corengia, P.; Van sint Annaland, M. Recent advances on membranes and membranes reactor for hydrogen production. Chem. Eng. Sci. 2013, 92, 40-66. [CrossRef]

87. Thomas, S.; Hamel, C.; Seidel-Morgenstern, A. Basic Problems of chemical reaction enginnering and potential of membrane reactors. In Membrane Reactors; Wiley-VCH Verlag GmbH \& Co. KGaA: Winheim, Germany, 2010; pp. 1-27.

88. Bernal, M.P.; Coronas, J.; Menendez, M.; Santamaria, J. Coupling of reaction and separation at the microscopic level: Esterification processes in a H-ZSM5 mebrane reactor. Chem. Eng. Sci. 2002, 57, 1557-1562. [CrossRef]

89. Peters, T.A.; Benes, N.R.; Keurentjes, J.T.F. Zeolite-coated ceramic pervaporation membranes; pervaporation-esterification coupling and reactor evaluation. Ind. Eng. Chem. Res. 2005, 44, 9490-9496. [CrossRef] 
90. De la Iglesia, O.; Irusta, S.; Mallada, R.; Menéndez, M.; Coronas, J.; Santamarìa, J. Preparation and characterization of two-layered mordenite ZSM5 bifunctional membranes. Microporous Mesoporous Mater. 2006, 93, 318-324. [CrossRef]

91. Vergunst, T.; Kapteijn, F.; Moulijn, J.A. Optimization of Geometric Properties of a Monolithic Catalyst for the Selective Hydrogenation of Phenylacetylene. Ind. Eng. Chem. Res. 2001, 40, 2801-2809. [CrossRef]

92. Bagnall, L.; Cavell, K.; Hodges, A.M.; Mau, A.W.; Seen, A.J. The use of catalytically active pervaporation membranes in esterification reactions to simultaneously increase product yield and permselectivity flux. J. Membr. Sci. 1993, 85, 291-299. [CrossRef]

93. David, M.O.; Nguyen, T.Q.; Neel, J. Pervaporation membranes endowed with catalytic properties, based on polymer blends. J. Membr. Sci. 1992, 73, 129-141. [CrossRef]

94. Zhang, W.; Qing, W.; Chen, N.; Ren, Z.; Chen, J.; Sun, W. Enhancement of esterification conversion using novel composite catalytically active pervaporation membranes. J. Membr. Sci. 2013, 451, 285-292. [CrossRef]

95. Ziobrowski, Z.; Kiss, K.; Rotkegel, A.; Nemest Othy, N.; Krupiczka, R.; Gubicza, L. Pervaporation aided enzymatic production of glycerol monostearate in organic solvents. Desalination 2009, 241, 212-217. [CrossRef]

96. Kita, H.; Tanaka, K.; Okamoto, K.; Yamamoto, M. The Esterification of Oleic Acid with Ethanol Accompanied by Membrane Separation. Chem. Lett. 1987, 16, 2053-2056. [CrossRef]

97. Yamamoto, M.; Munehisa, N.; Kaibara, M.; Horii, K.; Tanaka, K.; Kita, H.; Okamoto, K. Vapor-Permeation-Aided Esterification of Oleic Acid. Application of pressurized vapor circulation system and Zeolite membrane. Membrane 1995, 20, 143-148. [CrossRef]

98. Okamoto, K.I.; Kita, H. Zeolite NaA membrane: Preparation, single-Gas permeation, and pervaporation and vapor permeation of water/organic liquid mixtures. Ind. Eng. Chem. Res. 2001, 40, 163-175. [CrossRef]

99. Hasegawa, Y.; Nagase, T.; Kiyozumi, Y.; Hanaoka, T.; Mizukami, F. Influence of acid on the permeation properties of NaA-type zeolite membranes. J. Membr. Sci. 2010, 349, 189-194. [CrossRef]

100. Ameri, E.; Moheb, A.; Roodpeyma, S. Vapor-permeation-aided esterification of isopropanol/propionic acid using $\mathrm{NaA}$ and PERVAP ${ }^{\circledR} 2201$ membranes. Chem. Eng. J. 2010, 162, 355. [CrossRef]

101. Jafar, J.J.; Budd, P.M.; Hugher, R. Enhancement of esterification reaction yield using zeolite a vapour permeation membrane. J. Membr. Sci. 2002, 199, 117-123. [CrossRef]

102. Hasegawa, Y.; Abe, C.; Mizukami, F.; Kowata, Y.; Hanaoka, T. Application of a CHA-type zeolite membrane to the esterification of adipic acid with isopropyl alcohol using sulfuric acid catalyst. J. Membr. Sci. 2012, 415, 368-374. [CrossRef]

103. Unlu, D.; Hilmioglu, N.D. Bioadditive Synthesis from Glycerol by Esterification Using Catalytic Chitosan Membrane. In Progress in Clean Energy, Volume I: Analysis and Modeling; Dincer, I., Colpan, C.O., Kizilkan, O., Ezan, M.A., Eds.; Springer: Cham, Switzerland, 2015.

104. Cannilla, C.; Bonura, G.; Arena, F.; Rombi, E.; Frusteri, F. How surface and textural properties affect the behaviour of Mn-based catalysts during transesterification reaction to produce biodiesel. Catal. Today 2012, 195, 32-43. [CrossRef]

105. Lam, M.K.; Lee, K.T.; Mohamed, A.R. Homogeneous, heterogeneous and enzymatic catalysis for transesterification of high free fatty acid oil (waste cooking oil) to biodiesel: A review. Biotechnol. Adv. 2010, 28, 500-518. [CrossRef] [PubMed]

106. Farobie, O.; Matsumura, Y. A comparative study of biodiesel production using methanol, ethanol, and tert-butyl methyl ether (MTBE) under supercritical conditions. Bioresour. Technol. 2015, 191, 306-311. [CrossRef] [PubMed]

107. Demirbas, A. Comparison of transesterification methods for production of biodiesel from vegetable oils and fats. Energy Convers. Manag. 2008, 49, 125-130. [CrossRef]

108. Atadashi, I.M.; Aroua, M.K.; Aziz, A.R.A.; Sulaiman, N.M.N. Membrane biodiesel production and refining technology: A critical review. Renew. Sustain. Energy Rev. 2011, 15, 5051-5062. [CrossRef]

109. Shuit, S.H.; Ong, Y.T.; Lee, K.T.; Subhash, B.; Tan, S.H. Membrane technology as a promising alternative in biodiesel production: A review. Biotechnol. Adv. 2012, 30, 1364-1380. [CrossRef] [PubMed]

110. Cao, P.; Dubé, M.A.; Tremblay, A.Y. High-purity fatty acid methyl ester production from canola, soybean, palm, and yellow grease lipids by means of a membrane reactor. Biomass Bioenergy 2008, 32, 1028-1036. [CrossRef]

111. Waldburger, R.M.; Widmer, F. Membrane reactors in chemical production processes and the application to the pervaporation-assisted esterification. Chem. Eng. Technol. 1996, 19, 117-126. [CrossRef] 
112. Assabumrungrat, S.; Phongpatthanapanich, J.; Praserthdam, P.; Tagawa, T.; Goto, S. Theoretical study on the synthesis of methyl acetate from methanol and acetic acid in pervaporation membrane reactor: Effect of continuous flow modes. Chem. Eng. J. 2003, 95, 57-65. [CrossRef]

113. Okamoto, K.; Yamamoto, M.; Otoshi, Y.; Semoto, T.; Yano, M.; Tanaka, K.; Kira, H. Pervaporation-aided esterification of oleic acid. J. Chem. Eng. Jpn. 1993, 26, 475-481. [CrossRef]

114. Sarkar, B.; Sridhar, S.; Saravanan, K.; Kale, V. Preparation of fatty acid methyl ester through temperature gradient driven pervaporation process. Chem. Eng. J. 2010, 162, 609-615. [CrossRef]

115. Figueiredo, K.C.S.; Salim, V.M.M.; Borges, C.P. Ethyl oleate production by means of pervaporation-assisted esterification using heterogeneous catalysisi. Braz. J. Chem. Eng. 2010, 27, 609-617. [CrossRef]

116. Okamoto, K.I.; Yamamoto, M.; Noda, S.; Semoto, T.; Otoshi, Y.; Tanaka, K.; Kita, H. Vapor-permeation-aided esterification of oleic acid. Ind. Eng. Chem. Res. 1994, 33, 849-853. [CrossRef]

117. Rewagad, R.R.; Kiss, A.A. Modeling and simulation of a pervaporation process for fatty ester synthesis. Chem. Eng. Commun. 2012, 199, 1357-1374. [CrossRef]

118. Dörmő, N.; Bélafi-Bakó, K.; Bartha, L.; Ehrenstein, U.; Gubicza, L. Manufacture of an environmental-safe biolubricant from fusel oil by enzymatic esterification in solvent-free system. Biochem. Eng. J. 2004, 21, 229-234. [CrossRef]

119. Koszorz, Z.; Nemestothy, N.; Ziobrowski, Z.; Belafi-Bako, K.; Krupiczka, R. Influence of pervaporation process parameters on enzymatic catalyst deactivation. Desalination 2004, 162, 307-313. [CrossRef]

120. Chamberlain, R.; Borges, C.P.; Habert, A.C.; Nobrega, R. Fractionation of fusel oil coupling pervaporation and distillation. In Proceedings of the Seventh International Conference on Pervaporation Processes in the Chemical Industry, Reno, Nevada, 26 February-1 March 1995; Bakish, R., Ed.; Bakish Material Corporation: Englewood, NJ, USA, 1995; pp. 271-284.

121. Beatrice, C.; Di Blasio, G.; Lazzaro, M.; Cannilla, C.; Bonura, G.; Frusteri, F.; Asdrubali, F.; Baldinelli, G.; Presciutti, A.; Fantozzi, F.; et al. Technologies for energetic exploitation of biodiesel chain derived glycerol: Oxy-fuels production by catalytic conversion. Appl. Energy 2013, 102, 63-71. [CrossRef]

122. Salomón, M.; Coronas, J.; Menéndez, M.; Santamaría, J. Synthesis of MTBE in zeolite membrane reactors. Appl. Catal. A Gen. 2000, 200, 201-210. [CrossRef]

123. Assabumrungrat, S.; Kiatkittipong, W.; Praserthdam, P.; Goto, S. Simulation of pervaporation membrane reactors for liquid phase synthesis of ethyl tert-butyl ether from tert-butyl alcohol and ethanol. Catal. Today 2003, 79-80, 249-257. [CrossRef]

124. Yang, B.-L.; Goto, S. Pervaporation with reactive distillation for the production of ethyl tert-butyl ether. Sep. Sci. Technol. 1997, 32, 971-981. [CrossRef]

125. Norkobilov, A.; Gorri, D.; Ortiz, I. Process flowsheet analysis of pervaporation-based hybrid processes in the production of ethyl tert-butyl ether. J. Chem. Technol. Biotechnol. 2017, 92, 1167-1177. [CrossRef]

126. Aguirre, I.; Güemez, M.B.; van Veen, H.M.; Motelica, A.; Vente, J.F.; Arias, P.L. Acetalization reaction of ethanol with butyraldehyde coupled with pervaporation. Semi-batch pervaporation studies and resistance of $\mathrm{HybSi}^{\circledR}$ membranes to catalyst impacts. J. Membr. Sci. 2011, 371, 179-188. [CrossRef]

127. Cannilla, C.; Bonura, G.; Frusteri, L.; Frusteri, F. Glycerol Etherification with TBA: High Yield to Poly-Ethers Using a Membrane Assisted Batch Reactor. Environ. Sci. Technol. 2014, 48, 6019-6026. [CrossRef] [PubMed]

128. Kiatkittipong, W.; Intaracharoen, P.; Laosiripojana, N.; Chaisuk, C.; Praserthdam, P.; Assabumrungrat, S. Glycerol ethers synthesis from glycerol etherification with tert-butyl alcohol in reactive distillation. Comput. Chem. Eng. 2011, 35, 2034-2043. [CrossRef]

129. Vlad, E.; Bildea, C.S.; Bozga, G. Design and Control of glycerol-tert-butyl alcohol etherification process. Sci. World J. 2012, 2012. [CrossRef] [PubMed]

130. Frusteri, F.; Arena, F.; Bonura, G.; Cannilla, C.; Spadaro, L.; Di Blasi, O. Catalytic etherification of glycerol by tert-butyl alcohol to produce oxygenated additives for diesel fuel. Appl. Catal. A 2009, 367, 77-83. [CrossRef]

131. Ozbay, N.; Oktar, N.; Dogu, G.; Dogu, T. Effect of sorption enhancement and isobutene formation on etherification of glycerol with tert-butyl alcohol in a flow reactor. Ind. Eng. Chem. Res. 2012, 51, 8788-8795. [CrossRef]

132. Cannilla, C.; Bonura, G.; Mezzapica, A.; Frusteri, L.; Frusteri, F. An Original Catalytic Reactor Coupled with Tubular Membrane to Efficiently Produce Biofuels by Etherification of Glycerol with TBA. In Proceedings of the 5th International Conference on Engineering for Waste and Biomass Valorisation (WasteEng2014), Rio de Janeiro, Brazil, 25-28 August 2014; pp. 1235-1247. 
133. Cannilla, C.; Bonura, G.; Frusteri, L.; Frusteri, F. Batch reactor coupled with water permselective membrane: Study of glycerol etherification reaction with butanol. Chem. Eng. Process. 2015, 282, 187-193. [CrossRef]

134. Gaudin, P.; Jacquot, R.; Marion, P.; Pouilloux, Y.; Jérôme, F. Acid-Catalyzed Etherification of Glycerol with Long-Alkyl-Chain Alcohols. ChemSusChem 2011, 4, 719-722. [CrossRef] [PubMed]

135. Liu, F.; De Oliveira Vigier, K.; Pera-Titus, M.; Pouilloux, Y.; Clacens, J.-M.; Decampo, F.; Jérôme, F.; Weckhuysen, B.M. Catalytic etherification of glycerol with short chain alkyl alcohols in the presence of Lewis acids. Green Chem. 2013, 15, 901-909. [CrossRef]

(C) 2017 by the authors. Licensee MDPI, Basel, Switzerland. This article is an open access article distributed under the terms and conditions of the Creative Commons Attribution (CC BY) license (http:/ / creativecommons.org/licenses/by/4.0/). 